
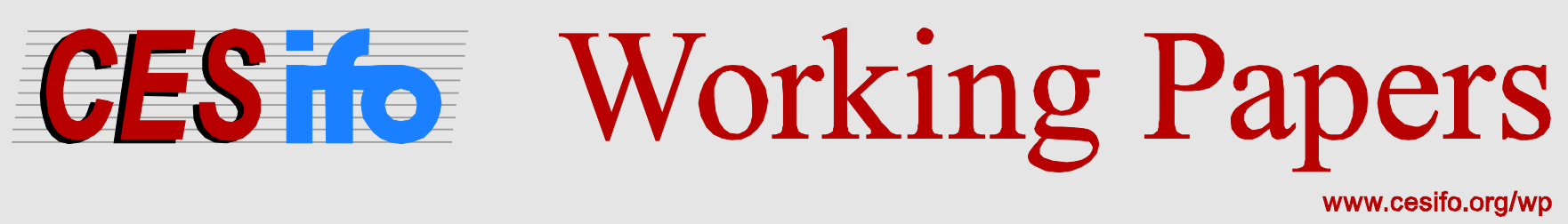

\title{
Evaluating Policies to Implement the Paris Agreement: A Toolkit with Application to China
}

\author{
Ian Parry \\ Baoping Shang \\ Nate Vernon \\ Philippe Wingender
}

\section{CESIFO WORKING PAPER NO. 6132 \\ CATEgORY 10: ENERGY AND ClimATE ECONOMICS \\ OCTOBER 2016}

An electronic version of the paper may be downloaded

- from the SSRN website:

- from the RePEc website:

- from the CESifo website:

WwW.SSRN.com

www.RePEc.org

www.CESifo-group.org/wp 


\title{
Evaluating Policies to Implement the Paris Agreement: A Toolkit with Application to China
}

\begin{abstract}
This paper describes a model, implemented in an Excel spreadsheet, for evaluating a wide range of fiscal and regulatory instruments policymakers might consider for implementing their Paris mitigation pledges. Policies are evaluated against a range of metrics, including impacts on carbon dioxide (CO2) emissions, revenue, deaths from local air pollution, economic welfare benefits and costs, and incidence across household and industry groups. The model is applied to China, the world's largest emitter, but could be readily transferred to most other countries.
\end{abstract}

JEL-Codes: Q480, Q540, Q580, H230.

Keywords: Paris Agreement, carbon tax, China, air pollution, coal tax, emissions trading, incidence, welfare effects, spreadsheet model.

\author{
Ian Parry \\ International Monetary Fund (IMF) \\ 700 19th Street, N.W. \\ USA - 20431 Washington DC \\ iparry@imf.org \\ Nate Vernon \\ nvernon32@gmail.com
}

\author{
Baoping Shang \\ International Monetary Fund (IMF) \\ 700 19th Street, N.W. \\ USA - 20431 Washington DC \\ bshang@imf.org \\ Philippe Wingender \\ International Monetary Fund (IMF) \\ 700 19th Street, N.W. \\ USA - 20431 Washington DC \\ pwingender@imf.org
}




\section{INTRODUCTION}

Over 190 countries made pledges to reduce carbon dioxide $\left(\mathrm{CO}_{2}\right)$ and other greenhouse gas emissions for the landmark 2015 Paris Agreement on Climate Change. The Agreement concluded that a typical large emitter's goal is expected to reduce emissions by around 30 percent by 2030 relative to emissions in some baseline scenario. The key practical issue is what specific policy actions are needed in different countries to move forward on these pledges.

There is a wide array of alternative fiscal and regulatory $\mathrm{CO}_{2}$ mitigation instruments - a nonexhaustive list includes carbon taxes; emissions trading systems (ETS); individual taxes on coal, road fuels, and electricity; renewables subsidies; measures to reduce the $\mathrm{CO}_{2}$ intensity of power generation; and policies to increase energy efficiency in different sectors.

Although there is general agreement among economists, policymakers, and business leaders ${ }^{1}$ that, ideally, comprehensive carbon pricing in line with environmental objectives would form the centerpiece of mitigation policy, there are practical reasons (e.g., opposition to large increases in energy prices) why policymakers may be under pressure to implement a more limited form of carbon pricing, perhaps in combination with other instruments. To make sound choices across instruments, to design the stringency of specific policies, and to communicate the case for policy actions to legislators and stakeholders, policymakers need an overarching quantitative framework for comparing options against a wide range of metrics including their effects on carbon dioxide $\left(\mathrm{CO}_{2}\right)$ emissions, revenue, premature deaths from local air pollution, incidence across household and industry groups, as well as their overall domestic economic benefits and costs.

While there has been plenty of valuable modelling of specific carbon mitigation policies in specific countries ${ }^{2}$, there has been little analysis comparing a broad range of policy options using a consistent modelling approach, and against a broad range of metrics. Probably the most comprehensive study in this regard is Krupnick et al. (2010) who examined the effectiveness and cost-effectiveness of over 30 policies and policy combinations to reduce US $\mathrm{CO}_{2}$ emissions and oil consumption using a variant of the National Energy Modelling System (NEMS). The NEMS model contains considerable detail on energy sectors, regions, and adoption of specific technologies, and its projections are widely used by other modelers, but conducting a simulation essentially requires hiring a specialist consultancy firm. In our view, a far more streamlined model - one that is easily run for different countries by nonexperts in a user-friendly spreadsheet — would be an especially useful tool, as it potentially

\footnotetext{
${ }^{1}$ See, for example, www.carbonpricingleadership.org/carbon-pricing-panel.

${ }^{2}$ See, for example, Aldy et al. (2016) and, for a discussion of modelling results for the United States, Fawcett et al. (2015).
} 
facilitates comparisons across instruments and countries, enables easy checks on the sensitivity of results to uncertain parameters, and regular updating for the latest energy data.

This paper takes a first stab at developing such a spreadsheet model and applies it in the case of China, the world's largest emitter, using each of the various mitigation instruments listed above. ${ }^{3}$ The tool, which distinguishes power generation, road transport and other energy use in industry and homes, begins with energy flow data for China from the International Energy Agency (IEA) website and projects this forward to 2030 using assumptions about GDP growth, income elasticities for energy products, future fuel prices, which vary based on policy action and stringency, and autonomous technological change. The responses to different policies hinge on behavioral response assumptions for fuel use, energy efficiency, and so on in different sectors, taken from the empirical literature.

To give a flavor of the results for China, taxes on the carbon content of fossil fuels, or just coal (both of which are very straightforward administratively), greatly outperform other policies across a broad range of metrics. In the central case, charges rising progressively to $\$ 35$ per ton ${ }^{4}$ of $\mathrm{CO}_{2}$ by 2030 reduce $\mathrm{CO}_{2}$ emissions by around a 20 percent relative to baseline levels (while meeting China's main Paris pledge on $\mathrm{CO}_{2}$ intensity) and raise revenues well over 1 percent of GDP in 2030. Cumulated over 2017-2030, these policies also save close to 2 million air pollution deaths while generating discounted domestic welfare gains (excluding climate benefits) equivalent to over 30 percent of 2015 GDP. These are extremely large benefits. An equivalently scaled ETS has - roughly speaking - about half of the environmental and (with auctioned allowances) fiscal effectiveness of the carbon and coal tax policies, while other policies often have dramatically lower environmental, fiscal, and welfare benefits. The relative ranking of different mitigation instruments is generally robust to parameter uncertainty.

Incidence analysis can be conducted by linking the policy-induced impacts on energy prices from the spreadsheet tool to an input-output model to trace through price impacts on different industries and consumer goods, and combining that with household survey data on spending

\footnotetext{
${ }^{3}$ The paper is based on a larger working paper written for the 2016 Article IV consultation between the IMF and China. As regards prior analyses of carbon policies for China, a valuable contribution is Cao et al. (2013) who analyze a carbon tax by integrating a detailed treatment of air pollution damages into an economic-energy model incorporating capital dynamics and disaggregating 33 different industries. With similar assumptions about the price responsiveness of coal use, our results on the carbon and local health benefits of carbon taxes are similar in a broad sense. The present analysis differs from Cao et al. (2013) by considering a wider range of carbon mitigation instruments, evaluating them against a broader range of metrics, and using a highly streamlined modelling approach. For a review of other recent carbon policy modelling exercises for China, see Karplus et al. (2016).

${ }^{4}$ Monetary figures are expressed in 2015 US\$ given the audience for the paper. To convert into Chinese Yen multiply by 6.5 .
} 
for energy and other products by different income groups. For China, carbon taxes are regressive but only moderately so - although the poor spend a greater share of their budget on electricity, natural gas, and heating than do wealthier households, the opposite applies for road fuels and other consumer products whose prices increase indirectly from higher energy costs. Recycling about 5 percent of the carbon tax revenues to lower social security contributions and stronger social safety nets - areas where China has been lagging 5 - could compensate the bottom two deciles. Carbon policies also complement broader efforts to rebalance the Chinese economy away from energy-intensive activities. Any transitory compensation for trade sensitive sectors should not involve large fiscal costs (around 10 percent of carbon pricing revenues) as these sectors are not disproportionately impacted by carbon mitigation policies.

The rest of the paper is organized as follows. Section 2 describes the model and policy scenarios. Section 3 presents the main policy comparisons. Section 4 discusses policy incidence. Section 5 concludes with some thoughts on the lessons for policymakers and future applications of the modelling toolkit.

\section{Analytical FrameWork}

A great deal about environmental, fiscal, and economic impacts of carbon mitigation policies can be learned from an aggregate-level (reduced form) model parameterized so baseline energy projections are consistent with those from more disaggregated (structural) models and the responsiveness of fuels to policies is consistent with empirical evidence. So long as the model contains the key features for distinguishing among the baseline scenario and alternative mitigation policies, additional disaggregation is not necessary for a first-pass policy assessment. These features include distinguishing the main energy sectors, fuel use within those sectors, and changes in energy efficiency from changes in the use of energyconsuming products. This section describes such a model and the policies it can analyze.

\section{A. Energy Sectors}

A discrete time period model is used where $t=0 \ldots \bar{t}$ denotes a particular year. Fossil fuels are first discussed, followed by fuel use in the power, road transport, and 'other energy' sectors. ${ }^{6}$

\footnotetext{
${ }^{5}$ Lam and Wingender (2015).

${ }^{6}$ Cross-price effects across the three sectors are not modelled as they are likely small for the time horizon due to products being poor substitutes for one another (e.g., higher prices for transport vehicles will have a minimal effect on the demand for space heating fuels).
} 
(i) Fossil Fuels. Five fossil fuels are distinguished - coal, natural gas, gasoline, road diesel and an aggregate of non-road oil products (e.g., for domestic aviation, petrochemicals) where these fuels are denoted by $i=C O A L, N G A S, G A S, D I E S$, and OIL respectively. The consumer fuel price at time $t$, denoted $p_{t}^{i}$, is:

(1) $p_{t}^{i}=\tau_{t}^{i}+\hat{p}_{t}^{i}$

$\tau_{t}^{i}$ is the tax on fuel $i$ including any excise or carbon charge. $\hat{p}_{t}^{i}$ is the pre-tax fuel price or supply cost which is exogenous, meaning fuel supply curves are perfectly elastic (for the most part, a reasonable longer run approximation). For fuels used in multiple sectors pre-tax prices and taxes are taken to be the same for all fuel users. Full pass through of fuel prices into consumer prices for electricity and other energy products is assumed and may in time be a reasonable approximation, even for China, given ongoing de-regulation of the energy sector. $^{7}$

(ii) Power Sector

Electricity demand. Residential, commercial, and industrial electricity uses are aggregated into one economy-wide demand for electricity in year $t$, denoted $Y_{t}^{E}$, and determined by:

(2) $Y_{t}^{E}=\left(\frac{U_{t}^{E}}{U_{0}^{E}} \cdot \frac{h_{t}^{E}}{h_{0}^{E}}\right) \cdot Y_{0}^{E}, \quad \frac{U_{t}^{E}}{U_{0}^{E}}=\left(\frac{G D P_{t}}{G D P_{0}}\right)^{v^{E}} \cdot\left(\frac{h_{t}^{E} p_{t}^{E}}{h_{t}^{E} p_{0}^{E}}\right)^{\eta^{U E}}, \frac{h_{t}^{E}}{h_{0}^{E}}=\left(1+\alpha^{E}\right)^{-t} \cdot\left(\frac{p_{t}^{E}}{p_{0}^{E}}\right)^{\eta^{h E}}$

$U_{t}^{E}$ is usage of electricity-consuming products or capital, implicitly the stock of electricityusing capital times its average intensity of use. $h_{t}^{E}$ is the electricity consumption rate (e.g., $\mathrm{kWh}$ per unit of capital usage), or the inverse of energy efficiency. Product usage increases with gross domestic product $\left(G D P_{t}\right)$ and $v^{E}$ is the (constant) income elasticity of demand for electricity-using products. Product usage also varies inversely with proportionate changes in unit electricity costs, or the user electricity price $p_{t}^{E}$ times the electricity consumption rate. $\eta^{U E}<0$ is the (constant) elasticity of demand for use of electricity-consuming products with respect to energy costs - a policy to increase energy efficiency without affecting the electricity price will therefore increase usage of electricity-consuming products through the 'rebound effect' (e.g., Gillingham et al. 2016). The electricity consumption rate declines (given other factors) at a fixed annual rate of $\alpha^{E} \geq 0$, reflecting autonomous energy efficiency improvements. Higher electricity prices increase energy efficiency, implicitly through adoption of more efficient technologies: $\eta^{h E}$ is the elasticity of the energy consumption rate with respect to energy prices. ${ }^{8}$

\footnotetext{
${ }^{7}$ In markets with regulated prices it can be very difficult to gauge what fraction of a new tax is absorbed in losses for state owned enterprises. Alternatively, the new taxes here might be interpreted as the nominal tax times the (presumably large) fraction that is passed forward.

${ }^{8}$ Note that data on $U_{t}^{E}$ and $h_{t}^{E}$ is not needed to implement the model.
} 
The assumption that price elasticities are constant over time is more reasonable if policies are fully anticipated and introduced gradually, providing households and firms with time to adjust, though the implications of gradual turnover of capital can be explored in the spreadsheet by using smaller nearer-term fuel price elasticities.

Mix of power generation fuels. Power generation fuels used in China include coal, natural gas, oil, nuclear, hydro, and (non-hydro) renewables (wind, solar, biofuels), where the latter are denoted by $i=N U C, H Y D$, and REN. To accommodate flexible assumptions for the degree of substitution among fuels, the share of fuel $i$ in generation, denoted $\theta_{t}^{E i}$, is defined:

$$
\theta_{t}^{E i}=\theta_{0}^{E i}\left\{\left(\frac{g_{t}^{i}}{g_{0}^{i}}\right)^{\tilde{\varepsilon}^{E i}}+\sum_{j \neq i} \theta_{0}^{E j}\left[1-\left(\frac{g_{t}^{j}}{g_{0}^{j}}\right)^{\tilde{\varepsilon}^{E j}}\right] / \sum_{l \neq j} \theta_{0}^{E l}\right\}
$$

where $i, j, l=C O A L, N G A S, O I L, N U C, H Y D, R E N . g_{t}^{i}$ is the cost of generating a unit of electricity using fuel $i$ at time $t$ and $\tilde{\varepsilon}^{E i}<0$ is the conditional own-price elasticity of generation from fuel $i$ with respect to generation cost. Conditional here (indicated by the $\sim$ ) means the elasticity reflects the percent reduction in use of fuel $i$ due to switching from that fuel to other generation fuels, per one-percent increase in generation cost for fuel $i$, conditional on a given amount of electricity. ${ }^{9}$ Generation cost elasticities are larger than (but easily inferred from) corresponding fuel price elasticities as an increase in all (fuel and nonfuel) generation costs has a bigger impact than an increase in fuel costs alone.

From (3) fuel $i$ 's generation share decreases in own generation cost and increases in the generation cost of other fuels, where the increase in fuel $i$ 's generation share is the reduced share for fuel $j \neq i$ times the (initial) share of $i$ in generation from all fuel alternatives to $j$.

Use of fossil fuel $i$ in power generation at time $t$, denoted $F_{t}^{E i}$, is given by:

(4) $F_{t}^{E i}=\frac{\theta_{t}^{E i} \cdot Y_{t}^{E}}{\rho_{t}^{E i}}$

Fuel use equals the generation share times total electricity output and divided by $\rho_{t}^{E i}$, the productivity of fuel use or electricity generated per unit of $F_{t}^{E i}$. The total supply of power generation in each period is assumed equal to total electricity demand.

\footnotetext{
${ }^{9}$ The size of the conditional generation cost elasticity is moderately smaller than that of the full generation cost elasticity - the latter would also incorporate reduced demand for all generation fuels as higher electricity prices lower electricity demand.
} 
Prices and costs. Unit generation costs are given by

$$
\begin{aligned}
& g_{t}^{E i}=\frac{p_{t}^{i}+k_{t}^{E i}}{\rho_{t}^{E i}}, i=C O A L, N G A S, O I L ; \quad g_{t}^{E i}=\frac{k_{t}^{E i}}{\rho_{t}^{E i}}-s_{t}^{E i}, i=N U C, H Y D, R E N ; \\
& s_{t}^{i}=0 \text { for } i \neq N U C, H Y D ; \quad \rho_{t}^{E i}=\left(1+\alpha^{\rho i}\right)^{t} \rho_{0}^{E i}
\end{aligned}
$$

$k_{t}^{E i}$ denotes capital, labor and other non-fossil fuel costs. Unit generation costs for fossil fuels decline with productivity improvements (assumed to reduce fuel and non-fuel costs by the same proportion). Similarly productivity improvements lower generation costs for non-fossil fuels and renewables receive a unit subsidy of $s_{t}^{E R E N}$. Productivity of generation by fuel $i$ increases at rate $\alpha^{\rho i} \geq 0$ per year implicitly from better production technologies and retirement of older, less efficient plants. Finally:

(6) $p_{t}^{E}=\sum_{i} q_{t}^{E i} \theta_{t}^{E i}+k_{t}^{E T}+\tau_{t}^{E}$

The consumer price of electricity is the product of the generation shares and unit generation costs summed over fuels, plus unit transmission costs, $k_{t}^{E T}$, and any excise tax on electricity consumption, $\tau_{t}^{E}$ (zero in the baseline). Upstream fuel taxes are therefore fully passed forward in higher electricity prices, implying an equivalency between taxing the carbon content of power generation fuels and taxing emissions at the point of combustion.

(ii) Road Transport Sector. In the road transport sector, two vehicle classes are distinguished according to fuel type, gasoline or diesel, denoted $i=G A S, D I E S$ respectively - the former (for China) represents cars and motorbikes while the latter trucks and buses. Analogous to (1), gasoline and diesel fuel demand at time $t$, denoted $F_{t}^{T i}$ is:

(7) $F_{t}^{T i}=\left(\frac{U_{t}^{T i}}{U_{0}^{T i}} \cdot \frac{h_{t}^{T i}}{h_{0}^{T i}}\right) F_{0}^{T i} ; \quad \frac{U_{t}^{T i}}{U_{0}^{T i}}=\left(\frac{G D P_{t}}{G D P_{0}}\right)^{v^{T i}} \cdot\left(\frac{h_{t}^{T i} p_{t}^{i}}{h_{0}^{T i} p_{0}^{i}}\right)^{\eta^{U T i}} ; \quad \frac{h_{t}^{T i}}{h_{0}^{T i}}=\left(1+\alpha^{h T i}\right)^{-t} \cdot\left(\frac{p_{t}^{i}}{p_{0}^{i}}\right)^{\eta^{h T i}}$

$U_{t}^{T i}$ is kilometers $(\mathrm{km})$ driven by vehicles with fuel type $i$ and $h_{t}^{T i}$ is fuel use per vehicle km (the inverse of fuel economy). Km driven in vehicle type $i$ increases with real GDP, according to the income elasticity of demand $v^{T i}$ and inversely with proportionate changes in fuel costs per $\mathrm{km} h_{t}^{T i} p_{t}^{i}$, where $\eta^{U T i}<0$ is the km driven elasticity with respect to per $\mathrm{km}$ fuel costs. ${ }^{10} \alpha^{T i} \geq 0$ is an annual reduction in the fuel consumption rate due to autonomous fuel economy improvements. Higher fuel prices also reduce fuel consumption rates (e.g.,

\footnotetext{
${ }^{10}$ The model abstracts from substitution between use of gasoline and diesel vehicles given the very different vehicle types and that the policy scenarios increase gasoline and diesel prices increase in roughly the same proportion as they emit similar amounts of carbon.
} 
through promoting engine efficiency increases or lighter weight materials) according to $\eta^{h T i} \leq 0$, the elasticity of the fuel consumption rate.

(iii) Other Energy Sector The other energy sector reflects an aggregation of all other energy use and includes industry (steel, cement, refining, chemicals, construction, etc.), non-road transport, and residences. In China, this sector uses coal, natural gas, (non-hydro) renewables, and (non-road) oil products. ${ }^{11}$

To distinguish policies affecting emissions from large industrial sources, the other energy sector is decomposed into large and small energy users, the latter representing households and small firms with emissions below a threshold ${ }^{12}$, denoted by $q=L A R G E, S M A L L$, respectively. Use of fuel $i$ in the other energy sector, by group $q$, at time $t$, denoted $F_{t}^{O q i}$, is:

(9) $F_{t}^{O q i}=\left(\frac{U_{t}^{O q i}}{U_{0}^{O q i}} \cdot \frac{h_{t}^{O q i}}{h_{0}^{O q i}}\right) F_{0}^{O q i} ; \frac{U_{t}^{O q i}}{U_{0}^{O q i}}=\left(\frac{G D P_{t}}{G D P_{0}}\right)^{v^{O i}} \cdot\left(\frac{h_{t}^{O q i} p_{t}^{i}}{h_{0}^{O q i} p_{0}^{i}}\right)^{\eta^{U O i}} ; \frac{h_{t}^{O q i}}{h_{0}^{O q i}}=\left(1+\alpha^{O i}\right)^{-t} \cdot\left(\frac{p_{t}^{i}}{p_{0}^{i}}\right)^{\eta^{h O i}}$

where $i=C O A L, N G A S, O I L$, and REN. The interpretation for (9) is analogous to that for (2) and (7) with $U_{t}^{O q i}$ and $h_{t}^{O q i}$ denoting respectively, usage of products requiring fuel $i$ at time $t$ by group $q$ and its fuel consumption rate. Parameters $v^{O i}, \eta^{U O i}, \eta^{h O i}$, and $\alpha^{O i}$ have analogous interpretations to previous notation and are taken to be the same across large and small users. Given the limited scope for substituting among different fuels used for very different products (compared with fuels producing a homogeneous product in the power sector), fuel switching possibilities are not modelled in the other energy sector.

(iv) Initial metrics for comparing policies and model solution $\mathrm{CO} 2$ emissions. $\mathrm{CO}_{2}$ emissions from fossil fuel use at time $t$ are:

$$
\sum_{j i} F_{t}^{j i} \cdot \mu^{C O 2 i}
$$

where $j=E, T, O$ denotes a sector and $\mu^{C O 2 i}$ is fuel $i$ 's $\mathrm{CO}_{2}$ emissions factor (zero for nonhydro renewables, hydro, and nuclear). There is significant variation in $\mathrm{CO}_{2}$ emissions factors among different coal types, but this is not really the case when (as here) emission rates are defined per unit of energy. The $\mathrm{CO}_{2}$ emissions factors for fuels are fixed, that is, the model does not allow for the possibility of reducing them through carbon capture and storage technologies (given the high $\mathrm{CO}_{2}$ prices needed for these technologies to be viable).

\footnotetext{
${ }^{11}$ Given the focus on policies to reduce fossil fuels, the model does not capture (non-combustion) $\mathrm{CO}_{2}$ emissions released, for example, during the cement-making process.

${ }^{12}$ A threshold of 26,000 tons of $\mathrm{CO}_{2}$ has been suggested for participation in the China ETS, though this has yet to be confirmed.
} 
Revenue. Revenue from fuel and electricity taxes, less renewables subsidies, is:

$$
\sum_{j i} F_{t}^{j i} \cdot \tau_{t}^{i}+Y_{t}^{E} \cdot \tau_{t}^{E}-s_{t}^{E R E N} \cdot \theta_{t}^{E R E N} \cdot Y_{t}^{E}
$$

Air pollution mortality. Deaths from fossil fuel air pollution, at time $t$, is:

$$
\sum_{i j} F_{t}^{j i} \cdot m_{t}^{j i}
$$

$m_{t}^{j i}$ is mortality per unit of (fossil) fuel $i$ used in sector $j$, which may differ by sector due to differing use of control technologies and local population exposure to emissions. ${ }^{13}$

Economic welfare gains. Formulas for measuring the domestic welfare gains of policies are described in Parry et al. (2016), Appendix C. These are based on well-established secondorder approximations (reflecting various triangles, rectangles, and trapezoids in fuel markets) from the literature (e.g., Harberger 1964) and capture domestic environmental benefits (principally reduced local air pollution and, far less importantly, reductions in congestion and other external costs of road vehicle use) less economic welfare costs (distortions in fuel markets created by, or exacerbated by, new policies). Climate benefits are excluded from the calculations given their global nature and dispute over their value.

\section{Model parameterization and solution. The International Energy Agency's Extended World} Energy Balances is used to aggregate fuel use by sector in China, the latest available year being 2013 (this data is available for around 160 countries). Current and future GDP data ${ }^{14}$ are from IMF sources while future fuel and commodity prices are calculated using an average of IEA and IMF projections, and behavioral response parameters are based on summaries of empirical evidence (with adjustment for China, in some cases, based on judgment). Details are provided in the Appendix.

The model is solved by first developing a baseline projecting fuel use by sector going forward to 2030 using equations of the model and projections of energy prices and GDP. The impacts of policies are then calculated by computing policy-induced changes in fuel prices from any new explicit or implicit charges. The generation shares in the power sector are then calculated and the resulting electricity price. Electricity and fuel prices are then used in

\footnotetext{
${ }^{13}$ Local air pollution causes a range of other damages beyond mortality (morbidity, impaired visibility, building corrosion, crop damage, lake acidification, etc.) but previous studies suggest their combined damages are modest relative to mortality damages (e.g., NRC 2009, WB/SEPAC 2007).

${ }^{14}$ The World Economic Outlook (WEO) data is used for real GDP from 2013 to 2021, which is the end of WEO's forecast. From 2020 to 2030, real GDP growth decreases linearly from 6 percent to 5 percent.
} 
determining proportionate changes in energy efficiency, use of energy products, fuel demand across the three sectors, and hence the environmental, fiscal, and economic impacts.

\section{Policies}

This subsection discusses the different policy instruments under 'moderate' and 'aggressive' stringency scenarios.

Carbon tax. A comprehensive tax on fossil fuel $\mathrm{CO}_{2}$ emissions promotes the full range of emissions mitigation opportunities (switching to cleaner fuels, improving energy efficiency, conserving on usage of energy-consuming products) across all sectors.

The best way to administer the tax would be to levy it upstream at the point of entry in the economy, for example, at the mine mouth for coal building off existing administrative structures for China's Resource tax ${ }^{15}$ and for petroleum products at the refinery or gas processing plants, while imported fuel would be taxed at the border. There are currently in China about 11,000 coal mines (though restructuring will likely close around 4,000 of them over the next few years) and far fewer petroleum refineries and gas processing plants. This would contrast, by orders of magnitude, with the number of transactions the tax administration would have to monitor to collect a carbon tax downstream. Alternatively, the tax could be levied on large emitters though, besides missing a substantial portion of emissions, measuring emissions is technically more challenging than measuring carbon content of fuel combustion, requiring a high level of technical expertise typically not found in tax administrations (Calder 2015).

Two carbon tax scenarios are considered, including a moderate case with the tax rate increasing in equal yearly increments of $\$ 2.5$ per ton from 2017 to reach $\$ 35$ per ton by 2030 and an aggressive case with yearly tax rates twice as high.

Coal excise. This policy (and its stringency) is the same as for the carbon tax, with charges just applied to coal use.

ETS. This policy, building on regional pilot schemes, has been announced for China starting in 2017 (though the caps are yet to be determined) and, to contain monitoring costs, is limited to emissions from power generators, large industrial sources, ${ }^{16}$ and domestic aviation, which amounts to about 50 percent of current economy-wide $\mathrm{CO}_{2}$ emissions. To facilitate policy

\footnotetext{
15 That is, adding a specific component to the ad valorem structure recently introduced. Alternatively, the tax could be set on coal processing plants which are far fewer in number than coal plants.

${ }^{16}$ Including petro and other chemicals, building materials, iron and steel, non-ferrous metals, and paper (see http://carbon-pulse.com/14353).
} 
comparisons, the ETS is modelled by its implicit tax, that is, the emissions price that would be established by the cap and (given equivalency between charges on carbon content and on emissions) with charges applying to fuels used in power generation and large industry for the same price trajectories as under the carbon tax.

Electricity excise. Excises on (mostly residential) electricity are applied in many countries (in part rationalized on environmental grounds), though their environmental effectiveness is limited as they do not promote switching to cleaner generation fuels or reductions beyond the power sector. Electricity taxes (applied to all uses) are considered, with the rates matched to the increase in electricity prices under the modest and aggressive carbon tax scenarios respectively.

Increased renewable generation subsidies. Here the focus is on renewables in power generation, given their greater potential for use in that sector (though intermittency and the geographic mismatch between sites and population centers limit scaling up). Renewable subsidies have limited effects on reducing $\mathrm{CO}_{2}$ emissions as they do not promote some fuel switching possibilities (e.g., from coal to gas and from these fuels to nuclear), nor do they reduce electricity demand, or emissions beyond power. Subsidies for renewable power generation in China amounted to $\$ 0.03$ per kWh in 2013 and moderate and aggressive scenarios are considered increasing the subsidy by 50 and 150 percent respectively above this level (higher subsidies than this start to imply negative generation costs). ${ }^{17}$

Reducing $\mathrm{CO}_{2} / \mathrm{kWh}$ in power generation. Another policy to reduce power sector $\mathrm{CO}_{2}$ is to impose a $\mathrm{CO}_{2} / \mathrm{kWh}$ standard. ${ }^{18}$ One fiscal analog of this policy is a tax/subsidy scheme involving taxes on relatively dirty generators - in proportion to the difference between the average $\mathrm{CO}_{2}$ per $\mathrm{kWh}$ across their plants and a pivot point emission rate-and subsidies for relatively clean generators - in proportion to the difference between their $\mathrm{CO}_{2}$ per $\mathrm{kWh}$ and the pivot point. A second fiscal analog is a carbon tax applied to the emissions content of power generation fuels with all the revenues recycled in a subsidy per unit of power generation (e.g., Bernard et al. 2007), which is how the policy is modelled here, with the carbon tax rates chosen to mimic those in the modest and aggressive carbon tax scenarios. All of these policies promote all opportunities for fuel switching to reduce power sector

\footnotetext{
${ }^{17}$ In principle, there is an economic rationale for combining carbon pricing with renewables incentives if this addresses additional market failures (e.g., the inability of firms developing, or pioneering use of, technologies to capture spillover benefits to other firms from their own 'learning-by-doing' experiences) though whether they warrant substantial renewable deployment incentives is not entirely clear (e.g., Dechezleprêtre and Popp 2016, Löschel and Schenker 2016).

${ }^{18}$ Credit trading would be required for the policy to be cost effective in a model (unlike the present one) with differences in abatement cost schedules across power generators.
} 
emissions, rather than just shifting to renewables (e.g., Krupnick et al. 2010), though they have a much weaker impact on electricity prices.

Increasing the efficiency of electricity-using capital. Regulations are commonly used to raise the efficiency of electricity-using capital. ${ }^{19}$ The policy scenario considered here provides an upper bound on effectiveness and cost-effectiveness in the sense that it implicitly improves the efficiency of all electricity-using capital (appliances, lighting, buildings, heating and cooling equipment, etc.), and with equalized incremental costs per ton of $\mathrm{CO}_{2}$ reduced across all products. ${ }^{20}$ The policy is modelled by applying an implicit tax (with rates equal to those in the electricity tax scenarios) to reduce the electricity consumption rate, but not applying it to the demand for electricity-using capital, hence usage increases slightly from the rebound effect.

Higher road fuel taxes. Road fuel taxes in China were $\$ 0.16$ and $\$ 0.13$ per liter for gasoline and diesel respectively in 2013. These taxes are the most effective policies for reducing road fuel use as they promote higher fuel economy and less driving. A modest scenario is considered where gasoline and diesel taxes are increased by the same amount as in the aggressive carbon tax and these tax increases are doubled for the aggressive scenario.

Fuel economy policies. Passenger vehicles have been regulated in China since 2005, the latest standards targeting new vehicle fuel consumption of 5 liters per $100 \mathrm{~km}$ (48 miles per gallon) by 2020 (UNEP 2015). Heavy-duty vehicles (trucks and buses), which consume diesel, are not subject to regulation. ${ }^{21}$ As the model does not distinguish vehicles of different vintages, an implicit policy raising average on road fuel economy progressively over time is considered. In the moderate scenario, the increase in fuel economy in each period matches that in the aggressive road fuel tax and in the aggressive fuel scenario, the increase in fuel economy in each period is twice that in the moderate fuel economy scenario.

Increasing efficiency in the other energy sector. The final policy increases the energy efficiency of fossil fuel-using capital for large users in the other energy sector (but not small

\footnotetext{
${ }^{19}$ Besides their environmental benefits, it is sometimes suggested that these policies address an additional market failure due to the private sector undervaluing the discounted energy savings from higher energy efficiency, though the evidence on this is mixed (e.g., Allcott and Wozny 2013, Helfand and Wolverton 2011). Allowing for this market failure could imply that, up to a point, policies to increase energy efficiency could have net economic benefits (before counting environmental benefits), though these benefits appear to be small relative to those from directly pricing emissions (e.g., Parry, Evans and Oates 2014).

${ }^{20}$ In reality, some capital is difficult to regulate (e.g. smaller appliances, audio and entertainment equipment, industrial processes such as assembly lines) and without extensive credit trading incremental costs may differ substantially across different efficiency programs.

${ }^{21}$ Implementing regulations for heavy trucks, for example, is complicated given that fuel economy is very sensitive to the weight of freight (see Harrington 2012).
} 
users who are more difficult to regulate). As above, the policy is modelled by applying an implicit tax to reduce the consumption rate of coal, natural gas, and oil products but not applying it to the price in the demand for use of energy products. The implicit tax is chosen to mimic the increase in fuel price under the modest and aggressive carbon tax scenarios.

\section{RESUlts}

This section discusses the baseline scenario, policy comparisons, sensitivity analyses, and a fully efficient pricing policy.

\section{A. Baseline Projections}

The baseline projections assume no new (or tightening of existing) policies beyond those implicit in observed data for 2013, aside from regulations resulting in a progressive reduction of local air pollution mortality rates and policies are then considered relative to this baseline. Inevitably, these projections are sensitive to different parameter assumptions, though this is less applicable to the relative policy comparisons which are the main focus of this paper.

Figure 1 shows baseline and $\mathrm{CO}_{2}$ emissions trends. GDP expands 131 percent between 2015 and 2030 (from IMF projections), while total energy consumption increases by 27 percent, implying a 45 percent decline in the energy to GDP ratio. $\mathrm{CO}_{2}$ per unit of energy remains about constant however, implying a similar decline in the $\mathrm{CO}_{2}$ to GDP ratio-although the productivity of zero-carbon fuels grows faster than for coal, this has little effect on reducing coal use per unit of energy, given lower future coal prices (see below) and limited substitution between fuels. The $\mathrm{CO}_{2}$ to GDP intensity in 2015 is 87 percent of the 2005 level $^{22}$ and declines to 45 percent of it by 2030, still substantially short of China's pledge for Paris to lower it by 60-65 percent below the 2005 level. Overall $\mathrm{CO}_{2}$ emissions are 21 percent higher in 2030 compared with $2015 .^{23}$

\footnotetext{
${ }^{22}$ Emissions intensity is 77 percent of the 2005 level in 2013 but then rises initially with the sharp decline in coal prices (and the immediate adjustment of the fuel mix in the model) to reach 87 percent by 2015 before declining.

${ }^{23}$ These energy demand and $\mathrm{CO}_{2}$ projections are broadly consistent with those from the range of energy models for China summarized in Mischke and Karlsson (2014), Figures 2 and 3-GDP growth is moderately larger in the present model, though this is offset by a faster decline in the energy intensity of GDP. The projected decline in the energy intensity of GDP is about a third smaller than in Green and Stern (2016), with part of the difference due to the counteracting effect (in the current model) of lower future energy prices. In addition, the $\mathrm{CO}_{2}$ intensity of energy is projected to fall by about 20 percent in Green and Stern (2016).
} 
There is little change in the composition of primary energy out to 2030 - the share of nonfossil fuel energy rises from 9 to 13 percent, while that for coal share falls from 66 to 63 percent. Given its high carbon intensity coal accounts for a disproportionately larger share, 82 percent in 2015, of $\mathrm{CO}_{2}$ than for primary energy, while natural gas accounts for 3 percent and (road and non-road) oil products 14 percent. In terms of sectors, electricity accounts for 40 percent of $\mathrm{CO}_{2}$ emissions in 2015, the transportation sector 7 percent, and the other energy sector 53 percent, and there is little change in these shares in the baseline.

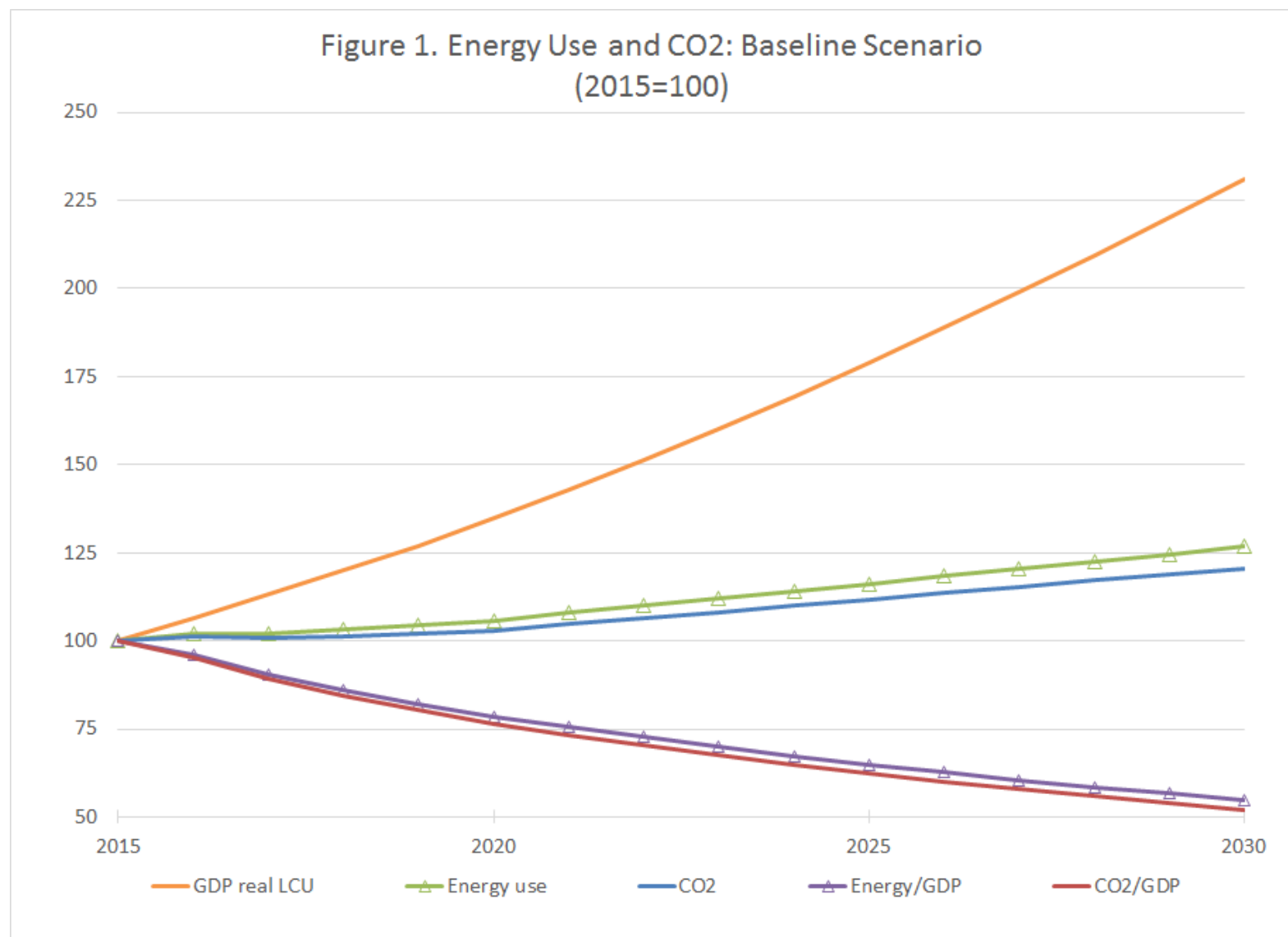

Source. Parry, Shang, Wingender, Vernon, and Narasimham (2016).

Note. The $\mathrm{CO}_{2}$ intensity of energy changes very little in the baseline, implying almost identical trends in energy and $\mathrm{CO}_{2}$, and in energy and $\mathrm{CO}_{2}$ intensities, relative to GDP.

Figure 2 indicates (real) energy price trends assumed in the baseline. All fossil fuel prices decline sharply between 2013 and 2016-by 62 percent for crude oil, about 31 percent for coal, 48 percent for natural gas, 45 percent for road fuels, and 12 percent for electricity - and thereafter rise slowly (or remain flat for electricity) but are still well below 2013 levels in 2030. Renewables prices, as proxied by power generation costs, fall by over 50 percent during the period (based on an assumed annual productivity growth rate of 4.5 percent). 
Finally, estimated annual deaths from fossil fuel air pollution are 1.12 million in $2015^{24}$ and rise to 1.3 million by 2030, with about half of the increase due to increased coal use and the other half rising population exposure to projected urban migration (Parry et al. 2016). Initially 53 percent of deaths are from coal combustion in the power sector and 42 percent from coal use in the other energy sector, however the share of power sector coal in total deaths drops to 28 percent by 2030 due to greater deployment of control technologies at coal plants which roughly halves the industry average air pollution emission rate by 2030 .

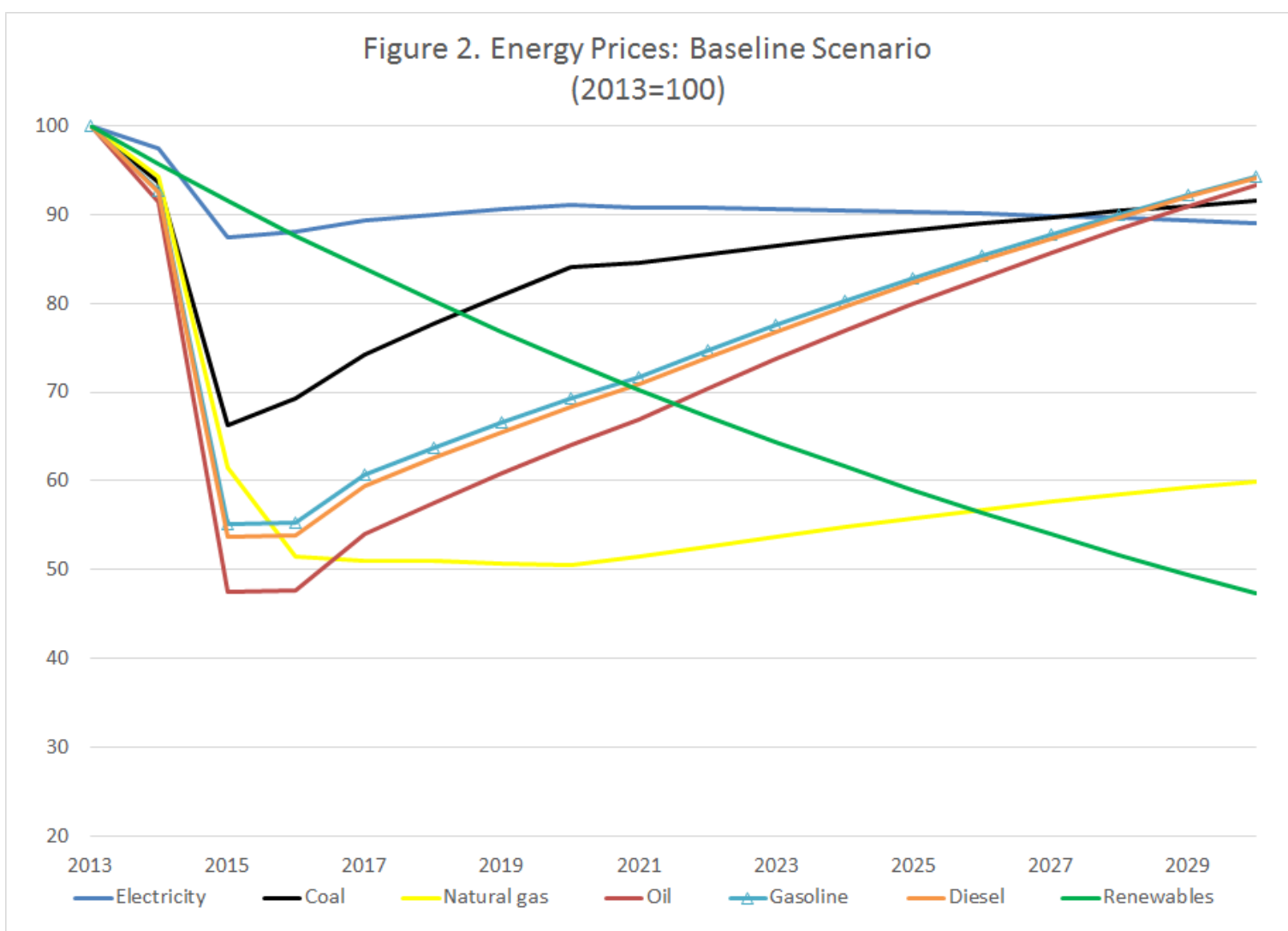

Source. IMF (2015) and authors assumptions.

Note. Gasoline and diesel prices follow identical trends. Renewables prices are renewable power generation costs. China recently introduced a domestic oil price floor of RMB 260 (\$40) per barrel of oil but this is nonbinding in our scenarios and is not reached in the baseline.

\footnotetext{
${ }^{24}$ This is significantly less than the estimate of outdoor air pollution deaths in the Global Burden of Disease project (Brauer et al. 2012), one potential explanation being that the latter also includes pollution from nonfossil sources (e.g., agriculture, plastics, refrigerants, landfills, mining).
} 


\section{B. Policy Comparison}

This subsection compares the impact of different policies on $\mathrm{CO}_{2}$, revenue, air pollution deaths, and economic welfare, relative to the baseline outcome.

(i) $\mathrm{CO}_{2}$ emissions. Figure 3 indicates the percent reduction (relative to the baseline level) in $\mathrm{CO}_{2}$ emissions in 2020 and 2030 under each policy and stringency scenario. The carbon tax is the most effective policy, reducing $\mathrm{CO}_{2}$ by 13 percent and 30 percent below baseline levels in 2020 and 2030 in the aggressive case, and by 7 percent and 19 percent in those years (both modest and aggressive taxes meet China's emissions intensity target) in the moderate case.

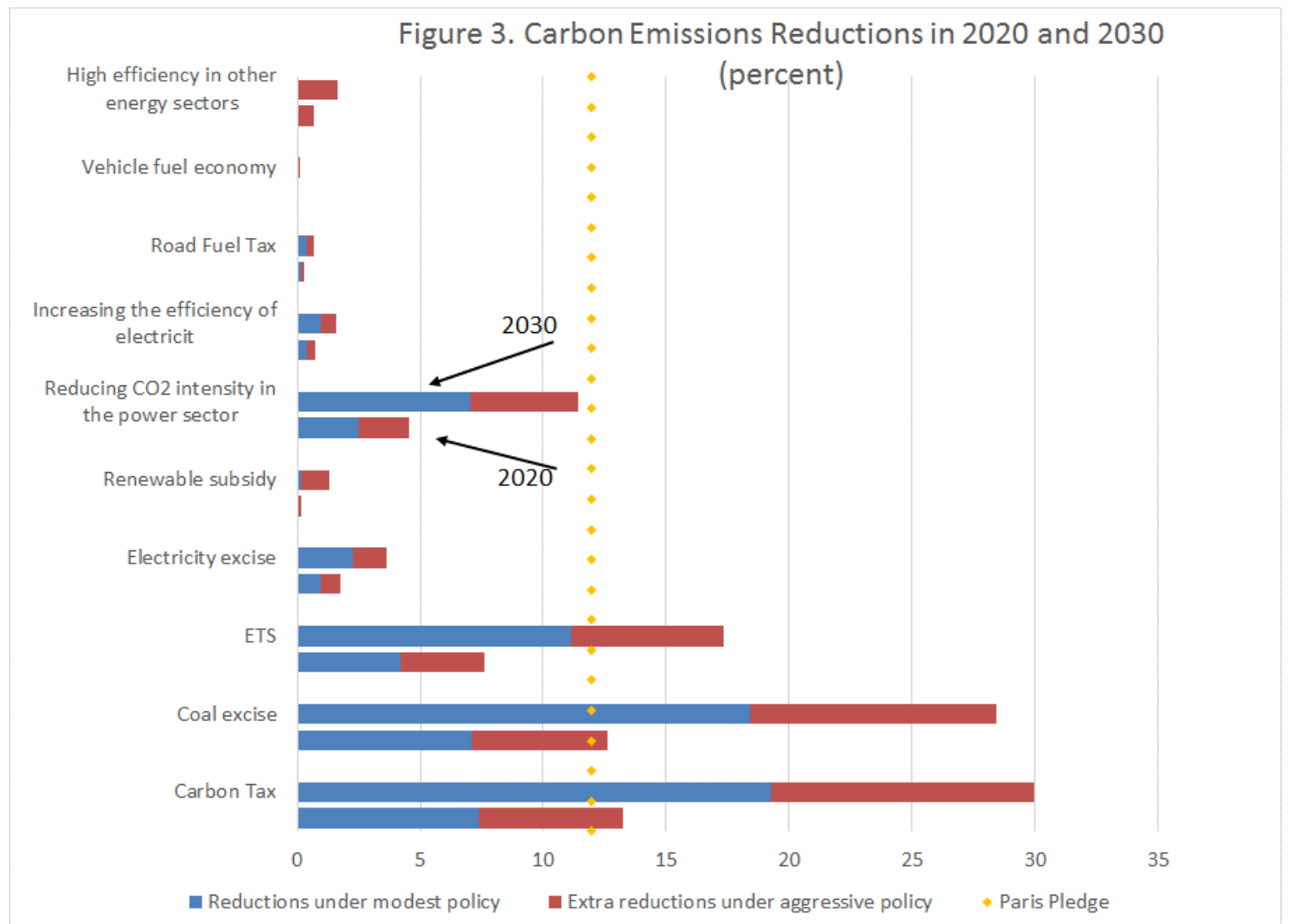

Source. Parry et al. (2016).

Notes. Bars indicate percent reductions in fossil fuel $\mathrm{CO}_{2}$ emissions relative to baseline emissions in that year. 
These results are driven by reductions in coal use, which account for 97 percent of the $\mathrm{CO}_{2}$ reductions. ${ }^{25}$ Doubling the carbon tax has a less than proportionate impact on $\mathrm{CO}_{2}$ reductions, given the standard assumption that fuel demand curves are convex. The coal tax reduces $\mathrm{CO}_{2}$ by 95-96 percent of the reductions under the carbon tax across years and stringencies, this small difference reflecting the relatively small emissions reductions forgone from failing to charge for $\mathrm{CO}_{2}$ from natural gas and oil.

The ETS has intermediate effectiveness, reducing emissions by about 57 percent of the reductions under the carbon tax across years and stringency scenarios. The ETS produces the same $\mathrm{CO}_{2}$ reductions from the power sector as under the carbon tax, but only a quarter of those from the other energy sector, as it does not cover small users, and none from road transportation. The power sector $\mathrm{CO}_{2} / \mathrm{kWh}$ intensity standard has about $30-40$ percent of the effectiveness of the carbon tax cross years and scenarios. The electricity excise has about 12 percent of the effectiveness of the carbon tax, that is, about 12 percent of the emissions reductions under the carbon tax comes from reductions in electricity demand. This reduction is split about equally between improvements in energy efficiency and less usage of electricity-using capital - hence the policy to increase the efficiency of electricity-consuming products has about 5 percent of the effectiveness of the carbon tax. ${ }^{26}$ The road transportation policies have very limited effectiveness, and the same applies for the enhanced renewable generation subsidy (as this builds off a small base) and the efficiency policy for the other energy sector (which applies only to large firms).

Although combinations of policies are not explicitly modelled, in many cases they are essentially additive. For example, a regulatory combination to reduce the $\mathrm{CO}_{2}$ intensity of power generation and improve energy efficiency across all three sectors has less than half of the effectiveness of the carbon tax.

\footnotetext{
25 The moderate tax in 2020 raises coal prices by 23 percent and reduces coal use by 9 percent. In contrast, road fuel prices increase by only about 3 percent, and in any case these fuels only accounted for 7 percent of economy-wide emissions in the baseline for 2020.

26 The rebound effect offsets about 10 percent of the energy savings from higher efficiency in the power sector, and similarly in the transport and other energy sectors.
} 


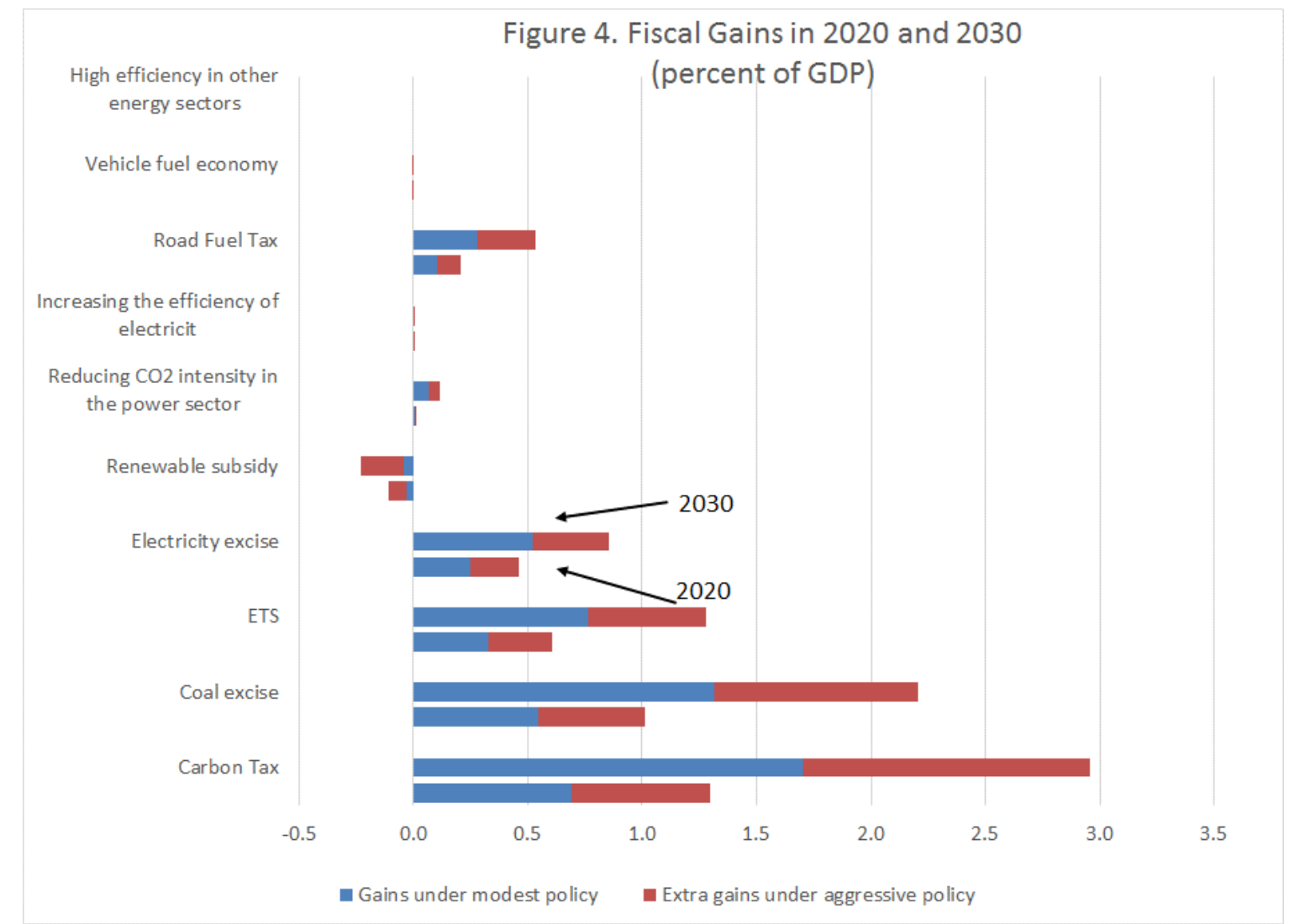

Source. Parry et al. (2016).

(ii) Revenue. As indicated in Figure 4, the carbon tax also has the greatest fiscal benefit, raising revenues of 1.7 percent and 3.0 percent of GDP in 2030 in the modest and aggressive scenarios. Although carbon tax rates are 3.5 times as high in 2030 compared with 2020 , revenues are only about a third higher relative to GDP because the baseline $\mathrm{CO}_{2}$ to GDP ratio is 50 percent lower in 2030 and the higher carbon taxes have a bigger impact on eroding the tax base. Again the coal tax is not far behind, raising revenues of 74-79 of those under the carbon tax across years and stringency scenarios. The ETS - if allowances are auctionedand the electricity tax are intermediate cases, raising revenues of about 45 and 30 percent respectively as under the carbon tax. Road fuel taxes raise about 18 percent of the revenue from the carbon tax. Policies to reduce the $\mathrm{CO}_{2}$ intensity of power generation and to improve energy efficiency in the power and other energy sectors have no revenue impacts. The renewable generation subsidy loses revenue, as does the vehicle fuel economy policy (which erodes the tax base of prior fuel taxes) but the losses are relatively small (less than 0.25 percent of GDP). 


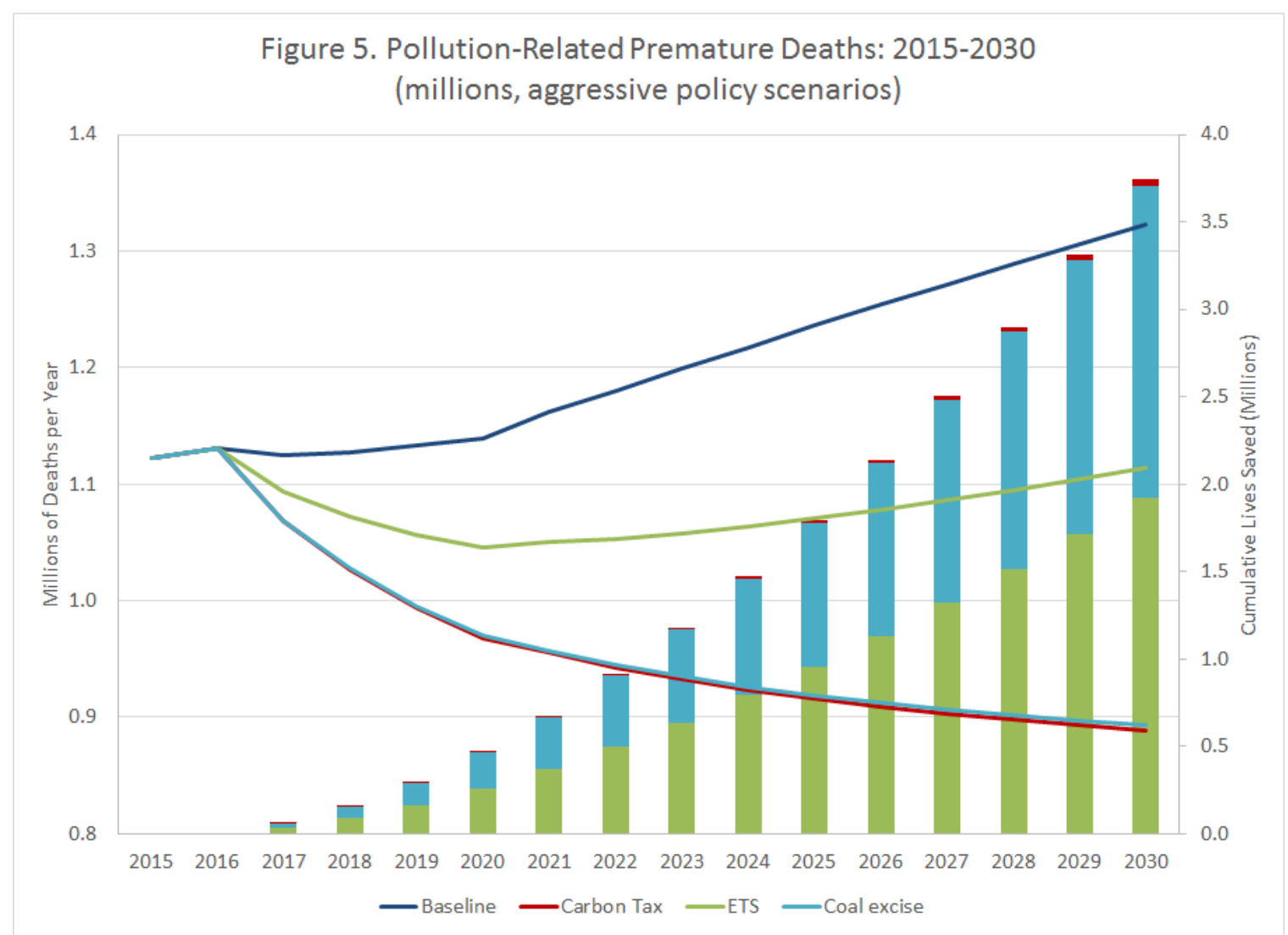

Source. Parry et al. (2016).

(iii) Local air pollution deaths. The percentage reduction in air pollution deaths in 2020 and 2030 for the major $\mathrm{CO}_{2}$ mitigation policies are fairly similar to the percentage $\mathrm{CO}_{2}$ reductions. For example, the modest carbon tax and coal tax both reduce deaths by about 9 percent in 2020 and 22 percent in 2030, while the aggressive versions of these taxes reduce deaths by 33 percent in 2030. The ETS reduces deaths between 5 and 20 percent across years and scenarios. More interesting perhaps is Figure 5 showing the time profile of air pollution deaths under selected policies in the aggressive scenarios. Lives saved (the difference between deaths in the baseline and under different policies) progressively increases over time as policies become more stringent. Cumulated over the 2017 to 2030 period, the carbon and coal taxes save about 3.7 million lives and the ETS about 1.9 million. 
Figure 6. Domestic Economic Benefits and Costs in 2030

(percent of GDP, aggressive policy scenarios)

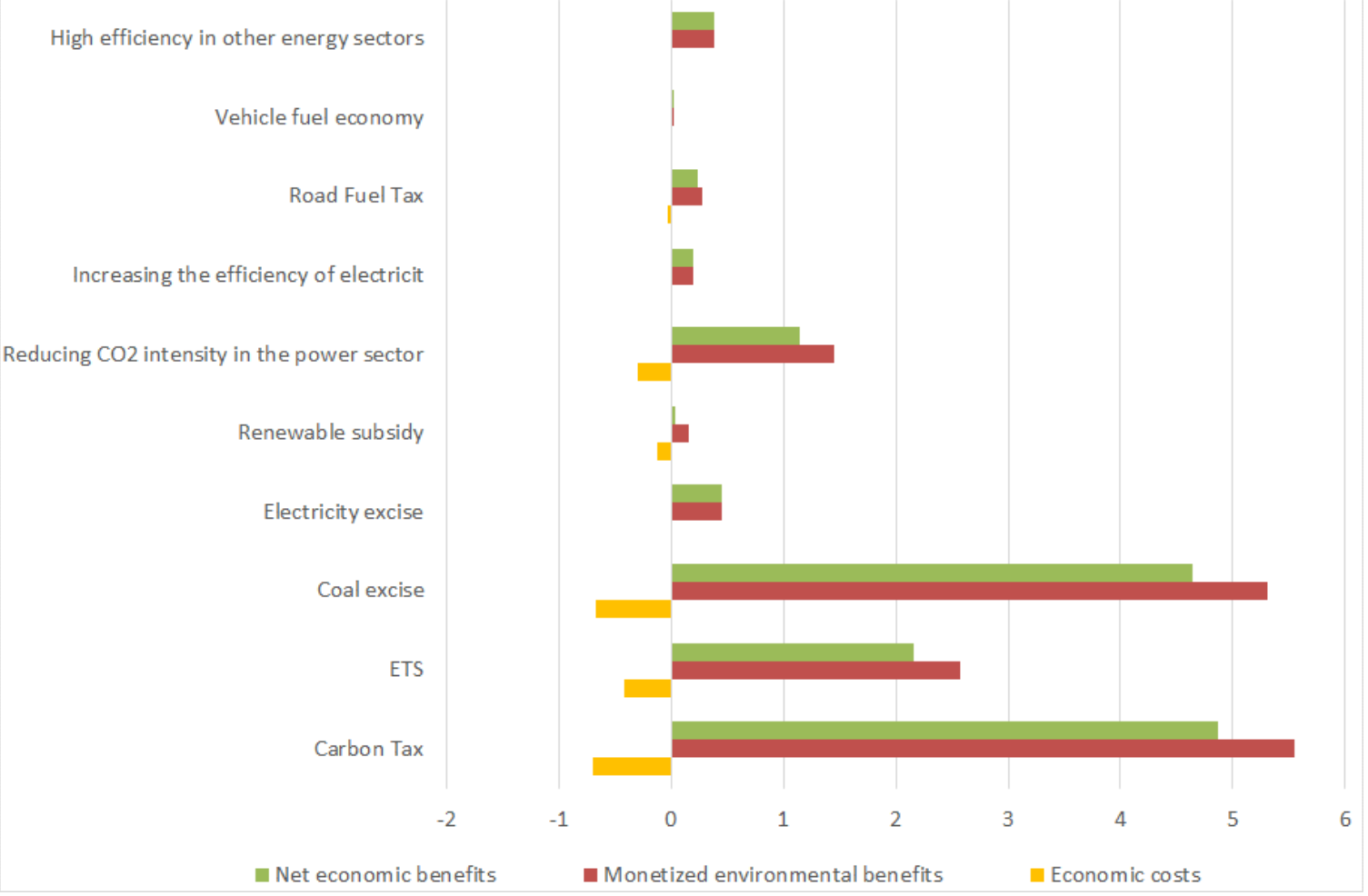

Source. Parry et al. (2016).

(iv) Domestic welfare benefits and costs. Figure 6 indicates the economic welfare costs, monetized domestic environmental benefits (essentially local air pollution benefits, excluding global climate benefits), and net welfare benefits (environmental benefits less economic costs) focusing on the aggressive policies for 2030. The carbon and coal tax perform far better than other policies, causing costs of about 0.7 percent of GDP, domestic environmental benefits approaching 6 percent of GDP, leaving a net welfare gain approaching 5 percent of GDP - a huge number. ${ }^{27}$ Net welfare gains are 2.2 percent of GDP under the ETS, 1.2 percent under the policy to reduce the $\mathrm{CO}_{2}$ intensity of power generation, and 0.5 percent of GDP or less under all other policies.

(v) Sensitivity analysis. Table 1 presents sensitivity analyses for the carbon and coal tax, ETS, and $\mathrm{CO}_{2} / \mathrm{kWh}$ policy for the moderate scenarios (see Parry et al. 2016 for details).

\footnotetext{
${ }^{27}$ For comparison, Robert Lucas once estimated that replacing capital taxes with (less distortionary) labor taxes in the United States would generate an annual welfare gain approaching one percent of GDP which he called "the largest genuinely free lunch I have seen in 25 years" (Lucas 1990, pp 314).
} 
The percent reduction in $\mathrm{CO}_{2}$ emissions under different policies is obviously sensitive to fuel price elasticities - for example, if the magnitude of fuel price elasticities is 50 percent larger, the percent $\mathrm{CO}_{2}$ reductions under different polices are increased by about 30-40 percent. Fossil fuel prices also matter-with IEA (2015) price projections, the percent $\mathrm{CO}_{2}$ reductions under different policies are about a third (in part because carbon charges have a smaller proportional impact on fuel prices). Changing income elasticities for energy products affects baseline $\mathrm{CO}_{2}$ emissions but has essentially no effect on the policy-induced percent reductions in $\mathrm{CO}_{2}$.

Table 1. Sensitivity Analysis: Moderate Policy Scenarios in 2030

\begin{tabular}{|c|c|c|c|c|c|c|c|c|c|c|c|c|c|c|c|c|c|}
\hline & & \multicolumn{4}{|c|}{$\mathrm{CO} 2$ reduction $(\%)$} & \multicolumn{4}{|c|}{ Revenue gain (\% of GDP) } & \multicolumn{4}{|c|}{ Cumulative lives saved (millions) } & \multicolumn{4}{|c|}{ PDV of welfare gain (\% of 2015 GDP) } \\
\hline & & $\begin{array}{l}\text { Carbon } \\
\text { tax }\end{array}$ & $\begin{array}{l}\text { Coal } \\
\text { excise }\end{array}$ & ETS & $\begin{array}{l}\text { Reducing } \\
\mathrm{CO} 2 / \mathrm{kWh} \\
\text { for power }\end{array}$ & $\begin{array}{c}\text { Carbon } \\
\text { tax }\end{array}$ & $\begin{array}{l}\text { Coal } \\
\text { excise }\end{array}$ & ETS & $\begin{array}{l}\text { Reducing } \\
\mathrm{CO} 2 / \mathrm{kWh} \\
\text { for power }\end{array}$ & $\begin{array}{c}\text { Carbon } \\
\text { tax }\end{array}$ & $\begin{array}{c}\text { Coal } \\
\text { excise }\end{array}$ & ETS & $\begin{array}{l}\text { Reducing } \\
\mathrm{CO} 2 / \mathrm{kWh} \\
\text { for power }\end{array}$ & $\begin{array}{c}\text { Carbon } \\
\text { tax }\end{array}$ & $\begin{array}{l}\text { Coal } \\
\text { excise }\end{array}$ & ETS & $\begin{array}{l}\text { Reducing } \\
\mathrm{CO} 2 / \mathrm{kWh} \\
\text { for power }\end{array}$ \\
\hline \multicolumn{2}{|l|}{ Central case } & 19.3 & 18.4 & 11.1 & 7.1 & 1.7 & 1.3 & 0.8 & 0.1 & 2.3 & 2.3 & 1.2 & 0.6 & 33.6 & 32.5 & 16.3 & 8.8 \\
\hline \multirow{2}{*}{$\begin{array}{l}\text { Income } \\
\text { elasticities }\end{array}$} & Low & 19.2 & 18.4 & 11.1 & 7.0 & 1.3 & 1.0 & 0.6 & 0.1 & 1.9 & 1.9 & 1.0 & 0.5 & 28.0 & 27.0 & 13.6 & 7.3 \\
\hline & High & 19.3 & 18.5 & 11.2 & 7.1 & 2.2 & 1.7 & 1.0 & 0.1 & 2.8 & 2.7 & 1.4 & 0.8 & 40.4 & 39.1 & 19.6 & 10.5 \\
\hline \multirow{2}{*}{$\begin{array}{l}\text { Price } \\
\text { elasticities }\end{array}$} & Low & 10.0 & 9.7 & 6.2 & 4.2 & 1.8 & 1.4 & 0.8 & 0.1 & 1.1 & 1.1 & 0.6 & 0.4 & 15.7 & 15.3 & 8.2 & 4.9 \\
\hline & High & 26.2 & 24.9 & 15.1 & 9.8 & 1.6 & 1.2 & 0.7 & 0.0 & 3.4 & 3.3 & 1.7 & 1.0 & 49.3 & 47.4 & 24.0 & 12.9 \\
\hline \multirow{2}{*}{$\begin{array}{l}\text { Productivity } \\
\text { growth }\end{array}$} & Low & 19.0 & 18.1 & 11.0 & 6.1 & 1.9 & 1.4 & 0.8 & 0.1 & 2.4 & 2.4 & 1.2 & 0.6 & 40.1 & 38.9 & 22.0 & 12.6 \\
\hline & High & 19.6 & 18.9 & 11.4 & 7.3 & 1.5 & 1.2 & 0.7 & 0.1 & 2.2 & 2.2 & 1.1 & 0.6 & 32.0 & 30.9 & 15.5 & 8.4 \\
\hline \multirow{2}{*}{$\begin{array}{l}\text { Fossil fuel } \\
\text { prices }\end{array}$} & Low & 27.1 & 25.7 & 14.5 & 8.9 & 1.5 & 1.1 & 0.7 & -0.1 & 3.4 & 3.4 & 1.6 & 0.8 & 49.5 & 47.5 & 21.4 & 10.4 \\
\hline & High & 12.5 & 12.1 & 7.7 & 5.2 & 1.9 & 1.5 & 0.9 & 0.1 & 1.4 & 1.4 & 0.8 & 0.6 & 20.8 & 20.2 & 11.0 & 7.6 \\
\hline \multirow{2}{*}{$\begin{array}{l}\text { Mortality } \\
\text { rates }\end{array}$} & Low & 19.3 & 18.4 & 11.1 & 7.1 & 1.7 & 1.3 & 0.8 & 0.1 & 1.5 & 1.5 & 0.8 & 0.4 & 21.4 & 20.5 & 10.6 & 5.8 \\
\hline & High & 19.3 & 18.4 & 11.1 & 7.1 & 1.7 & 1.3 & 0.8 & 0.1 & 2.7 & 2.7 & 1.6 & 1.0 & 40.0 & 38.9 & 22.7 & 13.8 \\
\hline \multirow{2}{*}{$\begin{array}{l}\text { Commodity } \\
\text { prices }\end{array}$} & WEO & 24.7 & 23.5 & 13.7 & 9.7 & 1.9 & 1.5 & 0.9 & 0.2 & 3.5 & 3.5 & 1.7 & 1.1 & 51.7 & 49.9 & 24.1 & 15.3 \\
\hline & IEA & 15.8 & 15.2 & 9.3 & 6.0 & 1.5 & 1.2 & 0.7 & 0.1 & 1.6 & 1.6 & 0.9 & 0.5 & 24.2 & 23.4 & 12.0 & 6.6 \\
\hline
\end{tabular}

Source. Parry et al. (2016).

Revenue gains from fiscal policies as a percent of GDP are moderately sensitive to income and elasticities and productivity trends (which affect future tax bases relative to GDP).

Cumulative lives saved over the 2017-2030 are sensitive to parameter variations as they affect either baseline deaths and/or policy responsiveness. For example, with higher fuel price elasticities the carbon and coal taxes save 3.4 million lives, while lives saved from the ETS drops to just under 1 million under a lower scenario for baseline air pollution deaths. Welfare gains (discounted over the 2017-2030 period and expressed as a percent of 2015 GDP) vary significantly in absolute terms but the relative welfare gains from policies are fairly robust - in all cases the ETS achieves about half of the welfare gains from the carbon and coal tax, and the $\mathrm{CO}_{2} / \mathrm{kWh}$ policy achieves about 25-35 percent of these gains. 
(vi) Comparison with a fully efficient policy. Parry et al. (2016) consider a fully efficient policy comprehensively charging fossil fuels for global and domestic environmental costs. This policy imposes much higher coal taxes (to reflect domestic air pollution costs) than the aggressive carbon tax. It reduces $\mathrm{CO}_{2}$ emissions in 2030 by 58 percent, reduces air pollution deaths by 63 percent, raises revenue of 8.5 percent of GDP, and generates a net domestic welfare gain (again, excluding global climate benefits) of 6.2 percent of GDP. ${ }^{28}$ Nonetheless, the aggressive carbon tax still performs reasonably well achieving 52 percent of the $\mathrm{CO}_{2}$ reductions as under the fully efficient policy, 52 percent of the air pollution deaths, and 79 percent of the domestic welfare gains in 2030, though the shortfall in fiscal benefits is more pronounced at 35 percent of those under the fully efficient policy.

\section{INCIDENCE ANALYSIS}

Having a sense of the distributional incidence of carbon pricing across household and industry groups is critical to informing policy dialogue and aiding in the design of accompanying measures (e.g., compensation schemes). Policies perceived as broadly fair in this regard are not only desirable for their own sake but also may stand a better chance of being enacted and sustained. Household and industry incidence are discussed in turn below, again using China to illustrate the application of analytical tools.

\section{A. Household Incidence}

(i) Methodology. A first pass estimate of the incidence on household groups from higher prices of consumer products caused by carbon pricing can be obtained by calculating firstorder consumer surplus losses using:

$$
\sum_{g} \pi_{t}^{h g} \cdot \rho_{t}^{h g}
$$

Here $h$ denotes a household income group, $g=1 \ldots G$ denotes major categories of consumer goods whose prices rise in response to carbon pricing, $\pi_{t}^{h g}$ is the share of household $h$ 's budget spent on good $g$ at time $t$ and $\rho_{t}^{h g}$ is the percent increase in the price of good $g$. According to this formula, if the budget share for a product is, say, 5 percent, a 10 percent increase in its price will decrease the household group's real income by the equivalent of 0.5 percent.

\footnotetext{
${ }^{28}$ A cautionary note here is that the uncertainties surrounding the effects of such dramatic policy changes are especially large.
} 
The budget shares for energy and non-energy products needed to implement (13) is available from household expenditure surveys, which are becoming increasingly common. ${ }^{29}$ The direct price impacts on energy products are an output of the previously described spreadsheet tool or can be inferred from $\mathrm{CO}_{2}$ emissions factors. ${ }^{30}$ Indirect impacts on the prices of other consumer goods can be estimated, assuming full pass through, from input/output tables ${ }^{31}$ dividing fuel and electricity purchases by fuel prices, and applying $\mathrm{CO}_{2}$ emissions factors, gives the embodied $\mathrm{CO}_{2}$ per $\$$ for each intermediate, and ultimately each consumer product, and multiplying by the $\mathrm{CO}_{2}$ price gives the product price increase. Input/output tables are also becoming more widely available (e.g., Trimmer et al. 2015).

There are a number of caveats to using formula (13) as the basis for incidence analysis.

For one thing, the $\mathrm{CO}_{2}$ emissions factor for power generation, and the embodied carbon in various energy products, will decline in response to carbon pricing, hence use of input/output tables leads to an overstatement of the consumer price increases from carbon pricing, though this overstatement is relatively modest for the level of carbon pricing envisioned for the near to medium term. Similarly, the formula in (13) overstates the loss of consumer surplus by ignoring reductions in demand for energy-intensive products in response to carbon pricing, though again the difference is relatively modest for non-dramatic carbon prices. ${ }^{32}$

Another caveat is that some (likely minor) fraction of the burden of carbon taxes may be passed backwards in lower producer prices, if fuel supply curves are upward sloping in the medium to longer term. To the extent this reduces the net of tax return to capital, some of the incidence of carbon pricing is borne by owners of capital, though if net of tax returns are largely determined in world markets the burden of lower producer prices is mainly borne by workers in the form of lower wages. The resulting incidence effects become difficult to estimate as they depend on whether energy-intensive firms disproportionately hire high- or

\footnotetext{
29 These surveys are routinely conducted for many advanced countries and the World Bank's Living Standards Measurement Study compiles them for approximately 40 developing countries.

${ }^{30}$ Fuel price increases are the carbon price times the fuel's $\mathrm{CO}_{2}$ emissions factor and the latter are well established and vary very little (per unit of energy for coal and natural gas and per liter for petroleum products) across countries. Approximate impacts on electricity prices can be inferred from the $\mathrm{CO}_{2}$ emissions per unit of electricity, which are available by country from the International Energy Agency. Baseline fuel prices (needed to convert absolute increases into percent increases) are available from an IMF database (www.imf.org/external/np/fad/subsidies/data/subsidiestemplate.xlsx).

${ }^{31}$ See for example Coady and Newhouse (2006).

${ }^{32}$ For example, the first-order approximation (a rectangle) overstates the loss of consumer surplus (a trapezoid) by only about 5 percent when demand for a fuel product falls by 10 percent. Substantial carbon prices may be implemented over a longer time horizon, but incidence analyses can be periodically updated with new household survey data to account for the impact of previous carbon price increases on budget shares.
}

(continued) 
low-wage workers, substitution elasticities between energy and other inputs, etc. (e.g., Fullerton and Heutel 2011), though some studies suggest these incidence effects are not that large and may lower the regressivity of carbon pricing. ${ }^{33}$

Furthermore, household survey and input/output data is backward looking. Incidence effects could be projected forward based on assumptions about how household consumption patterns and the energy intensity of different industries might change over time, though these trends are likely gradual - below we assume household spending patterns and industry structure in 2020 are the same as in 2012, the last year of available survey and input/output data. ${ }^{34}$

The appropriate definition of income against which carbon pricing burdens should be measured is also somewhat unsettled. Annual income is problematic given that many people with low annual income (e.g., students, people temporarily laid off or on maternity leave) are not poor in a life-cycle context, yet they contribute greatly to disparities in annual income across households. ${ }^{35}$ This problem is partly (though, because of constraints on consumption smoothing across the lifecycle, not fully) alleviated by measuring incidence against annual consumption expenditure rather than annual income. ${ }^{36}$

Yet another caveat is that here (as in other studies) the distributional incidence of the domestic environmental benefits of carbon pricing - principally the air pollution benefitsare not considered. Supposing (based on OECD 2012) that the valuation of health risks is roughly proportional to income, then these benefits may be skewed to lower income households if these households are more likely to reside in severely polluted areas. Again, the effects become complex however, if they raise property values in areas with improving air quality with adverse effects for low-income renters.

Finally, the overall incidence effects of carbon pricing will critically hinge on how revenues are used. Regressive impacts from energy price increases might be offset through cuts in social security contributions or increases in welfare and social spending targeted at the

\footnotetext{
${ }^{33}$ For example, Rausch et al. (2011).

${ }^{34}$ As long as any trends reduce energy budget shares for all household groups in roughly the same proportion, the relative incidence of carbon pricing across households should be largely unaffected. One exception might be the prospects for rising budget shares for gasoline among middle and lower income households with potential for growth in vehicle ownership rates among these groups.

${ }^{35} \mathrm{Up}$ to one-half of the inequalities in annual income across households might be attributed to variations in income over their life cycle rather than differences between life-cycle income (Lillard 1977).

${ }^{36}$ See for example Poterba (1991), Hassett et al. (2009).
} 
poorest households ${ }^{37}$ while the incidence implications of using revenues for cutting personal income, payroll, consumption, and corporate income taxes will depend on the specific parameters of a country's fiscal system and the degree of income inequality. ${ }^{38}$

(ii) Application to China. For China, household budget shares were obtained from the China Family Panel Studies (CFPS) data which provides household expenditures for 25 aggregated categories of goods and services. The latest year available for the survey is 2012 and includes information from a nationally representative sample of more than 13,000 households. ${ }^{39}$ Households were first separated into income deciles using consumption as a proxy for permanent income and budget shares were calculated by dividing expenditure on individual goods and services by total household consumption.

As illustrated in Figure 7, the fraction of total expenditure spent on energy declines sharply with income from about 10 percent for the bottom income decile to about 4 percent for the top decile. The large reductions in the budget shares between the $1^{\text {st }}$ and $2^{\text {nd }}$ deciles, and between the $9^{\text {th }}$ and $10^{\text {th }}$ deciles, reflect the high degree of income inequality at the bottom and top end of the income distribution in China (the poor being especially poor and the rich being especially rich). Lower-income groups also allocate a relatively higher share of energy expenditure to coal, electricity, heating, and natural gas while higher-income groups spend disproportionately more on gasoline. ${ }^{40}$

\footnotetext{
${ }^{37}$ See Dinan (2015) for an extensive discussion of options in the United States.

${ }^{38}$ Another noteworthy point is that if allowances in an ETS are given away for free to polluting firms, as happened for several pilot programs in China (OECD 2015), this transfers windfall gains to owners of capital in these firms (predominantly higher income households) which can greatly compound the regressive effects of carbon pricing (Parry 2004).

39 The CFPS is conducted by the Institute of Social Science Survey at Peking University and covers about 95 percent of the Chinese population in 25 provinces. Income distribution and poverty studies have found the CFPS to be consistent with other large-scale nationally representative household surveys in China, while Xi et al. (2014) find the sex-age structure of the 2010 CFPS survey closely tracks the 2010 Census.

40 The declining budget share for electricity is often observed for advanced economies (e.g., Morris and Mathur 2015), though not for low-income countries where the poor lack access to the power grid (e.g., Arze del Granado et al. 2012).
} 
Figure 7. Composition of Household Energy Expenditure by Income Group, 2012 (in percentages of total household expenditure)

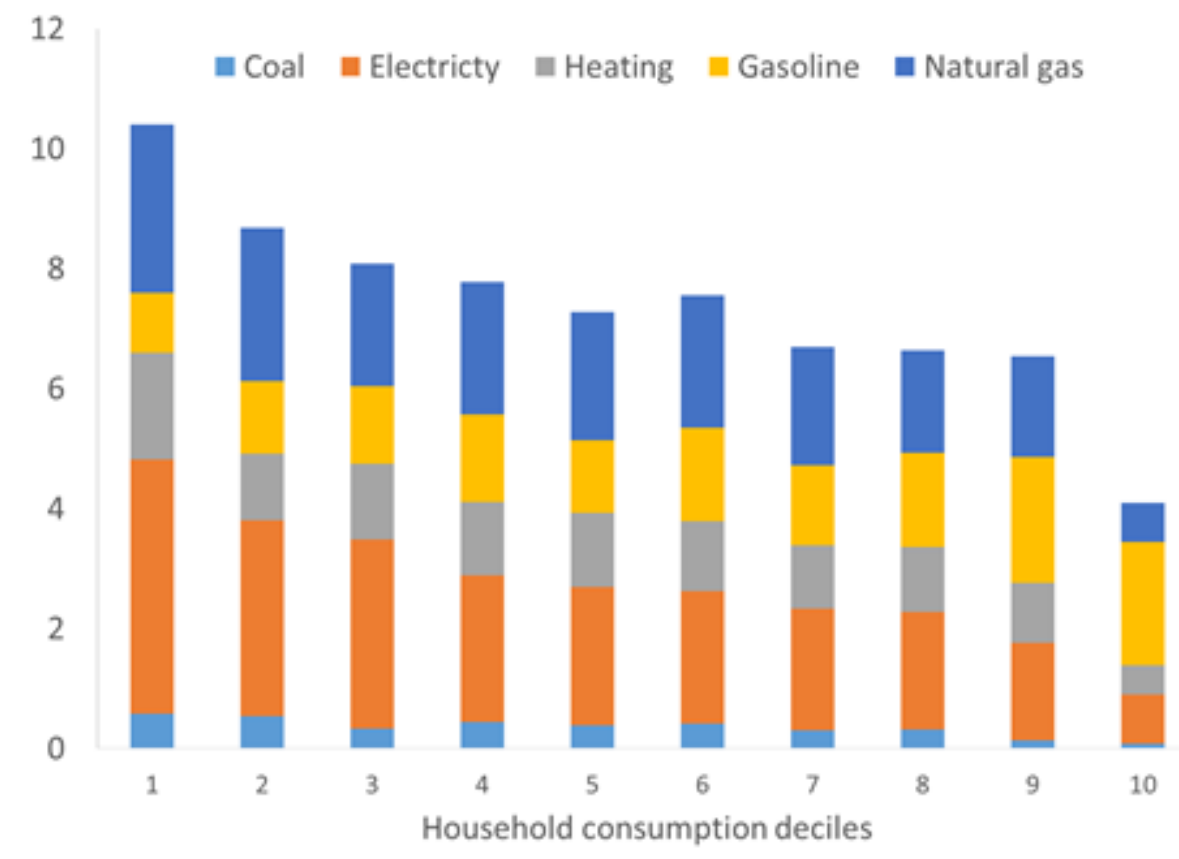

Source. IMF Staff estimates based on the CFPS 2012.

We also used China's national input-output table for 2012, the latest version published by the National Bureau of Statistics, which disaggregates 139 sectors. We look at the incidence of a $\$ 10$ per ton carbon tax for 2020 assuming the budget share and input/output data for 2010 is still applicable, and from the spreadsheet model this carbon price increases the price of coal by 23 percent, natural gas by 6 percent, and gasoline by 3 percent. The products most impacted by these energy price increases include water, furniture, transport and communications, and cars, however the impacts on food, medical expenses, clothing, and cigarettes and alcohol turn out to be more significant given the larger budget shares for these products.

Overall, the carbon tax increases consumer prices on average by around 1.1 percent in 2020, with the total effect regressive (Figure 8), though only mildly so- the burden for the bottom income decile is 1.4 percent of income and that for the top income decile is 0.9 percent. This mainly reflects burdens from the indirect price effects which are substantial and increase moderately (as a share of income) for higher income households. The incidence analysis of the other policies discussed above (the results are not presented here) reveal broadly similar patterns of relative incidence across the income distribution, though the degree of regressivity is even less pronounced for the regulatory measures. 
Figure 8. Impact of a Carbon Tax in China, 2020

(in percent of total household consumption)

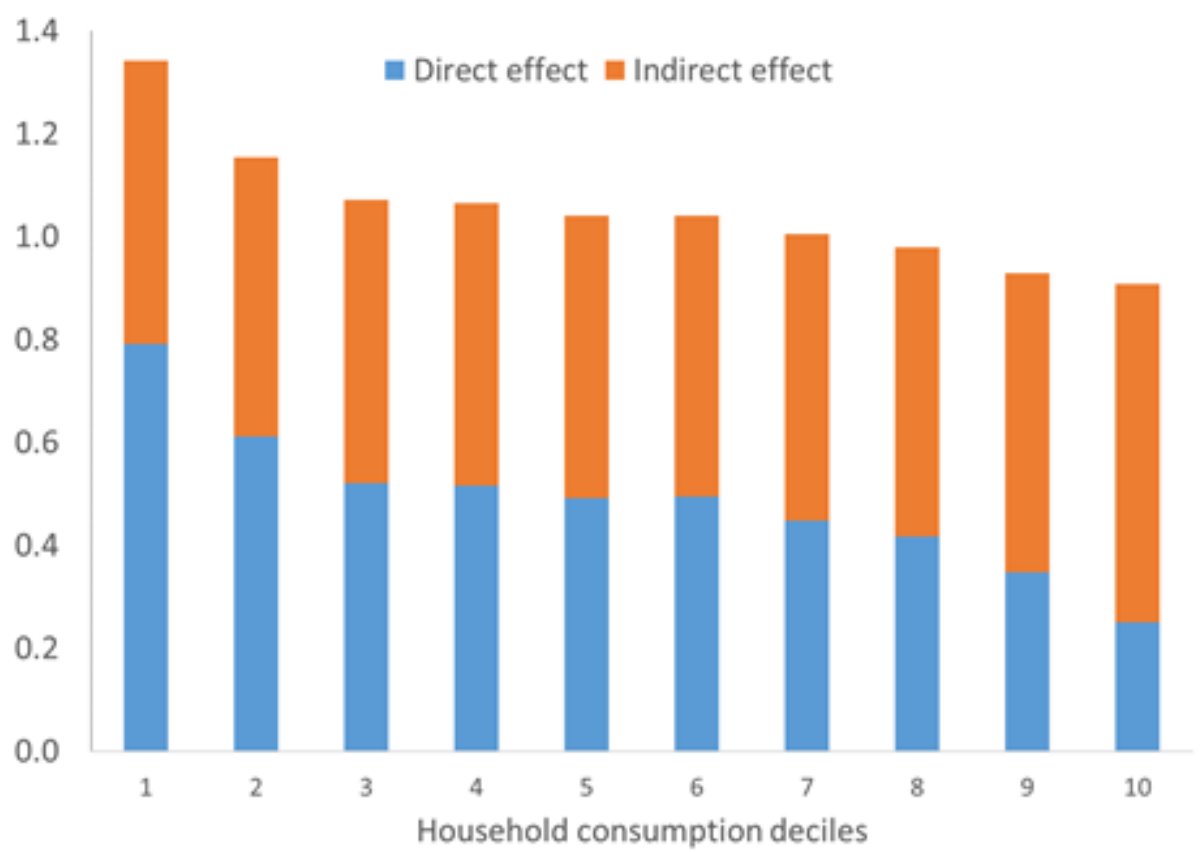

Source: IMF Staff estimates based on the 2012 CFPS and NBS 2012 input-output table.

Figure 9 compares distributional incidence when (as previously, and in line with many economists' recommendations) households are grouped by consumption, with incidence when households are grouped by annual income. Previous studies (mainly for advanced countries) find that carbon pricing is less regressive in the former case $\mathrm{e}^{41}$ but we find the opposite in the Chinese data - the burden of carbon pricing is approximately constant (1.1 to 1.3 percent of income) across different income groups. The difference in the degree of progressivity operates almost entirely through the direct impact of energy prices and is not due to any single source such as electricity or gasoline, but operates similarly for all energy sources.

\footnotetext{
${ }^{41}$ See, for example, Morris and Mathur (2015).
} 
Figure 9. Distributional Impact of a Carbon Tax: Consumption vs. Income (in percent of total household consumption)

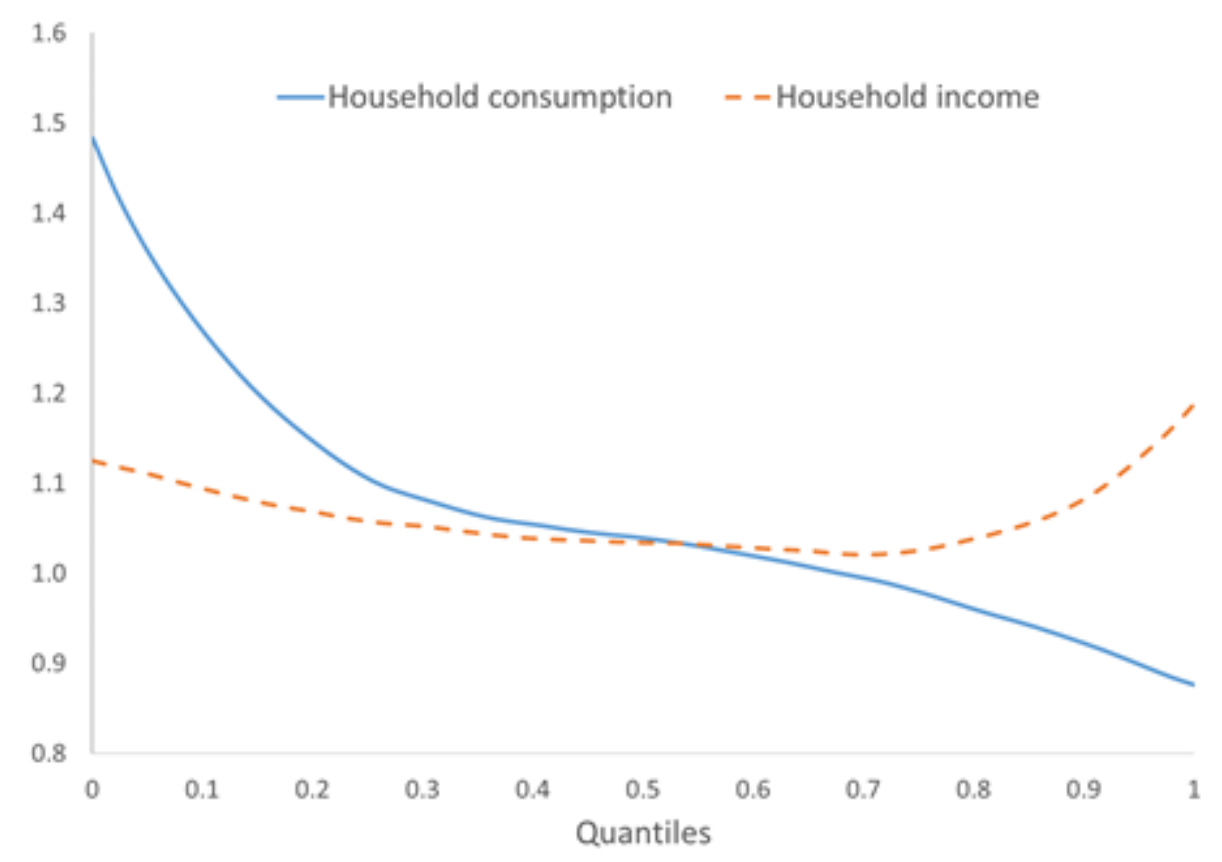

Source: IMF Staff estimates based on the 2012 CFPS and NBS 2012 Input-output table.

A potentially important implication of this finding is that is that if the government wishes to use fiscal transfers to compensate the poorest-which would require using less than 5 percent of the carbon pricing revenues - care should be given in the identification of the neediest households. In particular, using income as the basis for compensation might transfer more resources to income-poor households that in fact do not face such a large loss in purchasing power. On the other hand, identifying households based on aggregate consumption is quite data intensive and challenging. It might therefore be important to complement eligibility requirements for targeted compensation programs with other indicators of financial deprivation.

\section{B. Industry Incidence}

Carbon pricing increases production costs across all industries, a particular concern being impacts on energy-intensive and trade-exposed sectors. Besides reducing competitiveness, these impacts can lead to emissions leakage, though estimated leakage rates are not that dramatic $^{42}$, and some of the estimate reflects reductions in international fuel prices raising fuel demand in non-mitigating countries rather than migration of capital to these countries.

\footnotetext{
42 Typically between about 5 and 20 percent, depending on the size and composition of the coalition of countries pricing carbon (e.g., Böehringer et al. 2012).
} 
Competitiveness and leakage are ameliorated to the extent there is global action on mitigation, which is the idea underpinning the 2015 Paris Agreement.

Measuring the incidence of carbon pricing on different sectors using input-output tables is less contentious than incidence analysis for households, the main issues being whether there is full pass through of carbon pricing in energy prices, significant reductions in emissions or energy intensity in vulnerable sectors in response to carbon pricing, and possible changes in relative input prices from general equilibrium effects.

Figure 10 provides a preliminary sense of how the moderate carbon tax would increase costs across industries in China, by plotting the estimated increase in sectors' costs against their respective contribution to the country's total exports. While there is no clear pattern emerging, the sectors that contribute most to total exports are also among those that would face the smallest cost increase from higher energy prices - most of the hardest hit sectors are in fact those with small export shares.

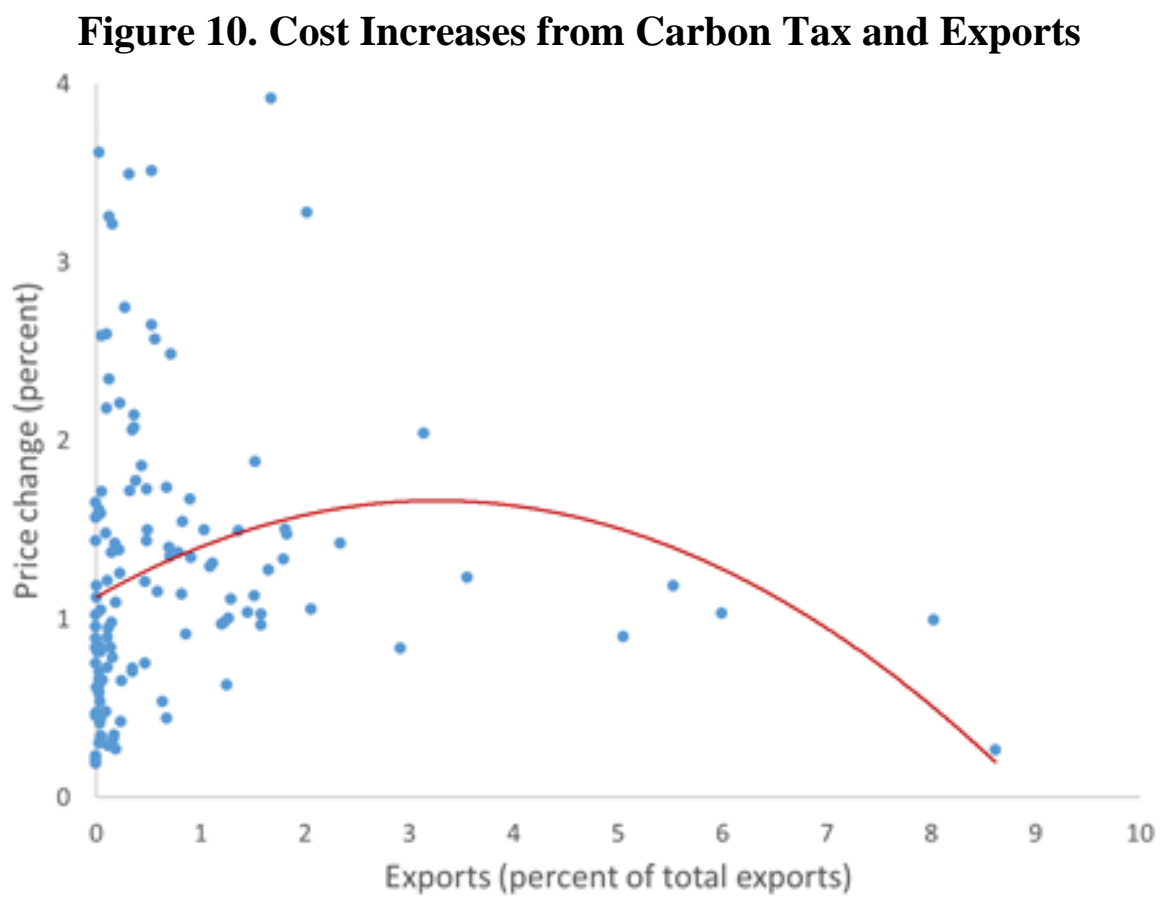

Source: IMF Staff estimates based on the NBS 2012 Input-output table.

Table 2 lists the 10 sectors most and least impacted by the introduction of a carbon tax based on energy intensity of production estimated from the input-output coefficient matrix. All the sectors listed in the top panel are heavy industries associated with China's 'old growth' model. In contrast, sectors that would experience the smallest cost increase are overwhelmingly in the service sector or in the consumer goods sectors such as tobacco and 
fishery. These results suggest that a carbon tax would also promote the rebalancing of the Chinese economy from heavy manufacturing, investment and real estate to services and consumption-led growth.

Table 2. Estimated Cost Increase from Moderate Carbon Tax, 2020

\begin{tabular}{lc}
\hline Sectors Most Affected & Cost Increase \\
Basic Chemical Raw Materials & 3.9 \\
Cement, Lime And Gypsum & 3.6 \\
Brick, Stone And Other Construction Materials & 3.5 \\
Fertilizer & 3.5 \\
Steel Flat-Rolled Products & 3.3 \\
Steel, Iron And Cast & 3.3 \\
Graphite And Other Non-Metallic Mineral Products & 3.2 \\
Chemical Fiber Products & 2.7 \\
Composites & 2.6 \\
Ferroalloy Products & 2.6 \\
& \\
Sectors Least Affected & \\
Real Estate & \\
Capital Market Services & 0.19 \\
Social Security & 0.21 \\
Wholesale And Retail & 0.23 \\
Insurance & 0.27 \\
Monetary And Financial And Other Financial Services & 0.27 \\
Education & 0.29 \\
Tobacco Products & 0.30 \\
Entertainment & 0.32 \\
Fishery Products & 0.33 \\
\hline Sour & 0.34 \\
\hline
\end{tabular}

Source: IMF Staff estimates based on the NBS 2012 Input-output table.

Similar results can also be easily estimated for sectors' share of value added and labor intensity. Panel a) in Figure 11 displays a strongly negative correlation between cost increases from a moderate carbon tax and the degree of value added by sector. This again suggest that a carbon tax would promote rebalancing by affecting relatively less the cost structure of sectors with high value added. We find a similar pattern for labor share of total output by sector in panel b). This suggests that labor intensive sectors would benefit more in relative terms, thereby promoting a rising share of labor and household income.

The bottom line is that competitiveness impacts of carbon pricing in China are not overly severe - in fact, even if China moves forward unilaterally with carbon pricing, trade-exposed 
firms could be fully compensated for higher energy costs using about 10 percent of the carbon pricing revenues.

\section{Figure 11. Sectoral Cost Increase and Rebalancing Indicators}
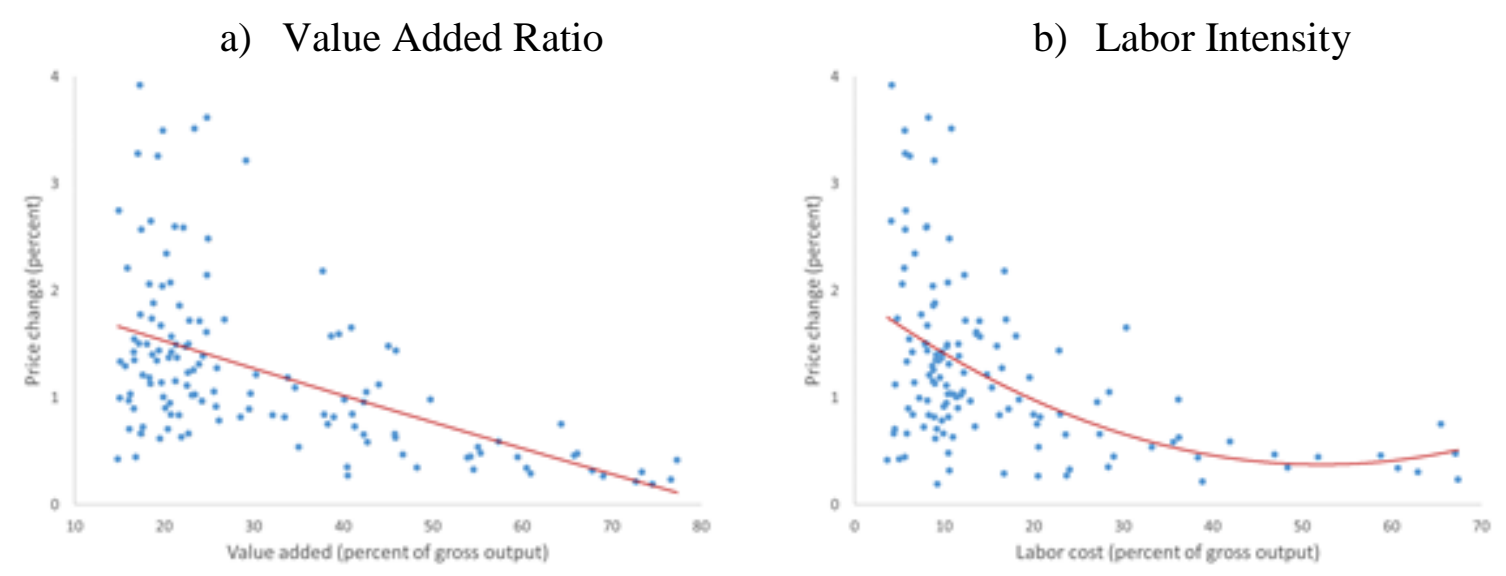

Source: IMF Staff estimates based on the NBS 2012 Input-output table.

\section{Conclusion}

This paper describes a flexible model, implementable in a spreadsheet, for providing a firstpass comparison of a wide range of $\mathrm{CO}_{2}$ mitigation policies across key metrics of concern to policymakers and applied it to China, though the tool can be readily applied to most other countries with publicly available data. While many of the qualitative insights from the above analysis might have been anticipated - for example, applying the same charge to a wider range of emissions is obviously more effective at reducing emissions - it is still critical to understand the quantitative impacts of policies and the key factors determining them. This informs policymakers of the trade-offs in instrument choice, the specific actions needed to make headway on emissions commitments, and the broader (e.g., fiscal, public health, incidence) implications of these measures. More generally, future use of these sorts of tools for cross-country comparisons (based on consistent methodology and data) may be useful as countries revise their Paris mitigation commitments, taking into account the actions of others.

For China, the results underscore the drawbacks of a downstream ETS missing about half of coal use, and therefore forgoing roughly half of the emissions reductions, half of the lives saved, and half of the fiscal benefits of upstream charging systems covering all coal use. Upstream charges, moreover, could easily build off existing resource tax administration levied at the mine mouth. Although the government is committed to introducing an ETS in 2017 , this should not preclude the simultaneous introduction of an upstream carbon or coal tax (perhaps, if tax rates are sufficiently aggressive, with some tax rebates for firms required to obtain emissions allowances). 
We would expect some of the results, such as the relatively limited environmental and fiscal effectiveness of road fuel and electricity taxes and incentives for renewable generation and energy efficiency, to carry over, in a broad sense, to other countries. Other results however, such as the strong environmental and fiscal advantages of carbon/coal taxes over ETS, will be less pronounced for other countries where coal is a minor share of $\mathrm{CO}_{2}$ emissions or where (as in the United States) coal use is confined to the power and large industrial sectors.

There are multiple dimensions for refining the spreadsheet tool by incorporating additional policies (e.g., for biofuels) and country-specific factors (e.g., cross-border mobility of fuels), so long as transparency and accessibility to the non-specialist is preserved. One complementary direction for future research might be to develop a computable general equilibrium analogue with greater sophistication (e.g., capital dynamics, endogenous technological change) that can be collapsed to replicate the spreadsheet model, thereby informing on how additional modelling detail improves the accuracy of the policy results and providing guidance on possible 'offline' adjustments to the spreadsheet tool.

\section{Appendix A. Parameterization}

Here we discuss data to parameterize the model (mostly for 2013 to be projected forward) ${ }^{43}$

Fuel prices and taxes. Pre-tax prices for coal, natural gas, gasoline, diesel, and oil products for 2013 are from an IMF database on international prices. These prices are then projected forward to 2030 based on splitting the difference between IMF and IEA (2015) projections of international commodity price indices for coal, natural gas, and crude oil. Also from IMF sources, pre-tax excises for gasoline and diesel are $\$ 0.16$ and $\$ 0.13$ per liter and zero for other fossil fuels.

Power sector. From IEA (2016), electricity consumption for China in 2013 was 386,971 kilotons of oil equivalent (ktoe). ${ }^{44}$ Empirical studies for various countries suggest a range for

\footnotetext{
${ }^{43}$ For a more in-depth discussion and ranges for sensitivity analyses, see Parry et al. (2016).

${ }^{44}$ Generation, rather than consumption, is what matters for fuel use and emissions, though the difference between them (reflecting electricity exports and imports) is less than 1 percent.
}

(continued) 
the income elasticity of electricity-using products of around $0.5-1.5 .{ }^{45}$ However, China is undergoing a structural rebalancing ${ }^{46}$ that is lowering the energy intensity of GDP and a smaller value $(0.5)$ is used so trends are in line with other projections (see text). Based on empirical evidence for a range of countries (see Parry et al. 2016), the price elasticities for usage of electricity products and the electricity consumption rate are both taken to be -0.25 . The annual rate of efficiency improvement for electricity-using products (which is of modest importance for the results) is taken from Cao et al. (2013) to be 0.01.

Generation shares are obtained from IEA (2016) by electricity produced from a fuel divided by total electricity production. The price responsiveness of coal (in the power and other energy sector) is the most critical parameter determining the effectiveness of major $\mathrm{CO}_{2}$ mitigation policies in China. A value of -0.35 is used based on empirical evidence for China and other counties (Parry et al. 2016), which - dividing by the share of fuel costs in coal generation costs - implies a generation cost elasticity of - 0.6 . Evidence to parameterize other generation cost elasticities is less solid and the same generation cost elasticity is used for other fuels, though the results (for China) are not especially sensitive to different values.

Fossil fuel inputs into the power sector for 2013 are from IEA (2016) and fuel productivity is electricity produced by that fuel divided by fuel input. For coal plants annual average productivity growth during 2003 to 2013 was 2 percent, though IEA (2015) Figure 2.16 projects lower future growth of around 0.5 percent (as assumed here), not least because average coal plant efficiency in China has surpassed that in advanced countries. For natural gas, nuclear and hydro, there is likely more room for productivity improvements and a growth rate of 2 percent is assumed. For non-hydro renewables, annual productivity growth from 2003 to 2013 was the most striking at 6 percent, though this seems unlikely to be sustainable out to 2030 - a productivity growth rate of 4.5 percent is used, and, lastly, for hydro, annual productivity growth of 0.005 percent is assumed.

For coal plants, non-fuel generation costs are taken to be two-thirds as large as 2013 fuel costs, ${ }^{47}$ or $\$ 0.03$ per $\mathrm{kWh}$. For natural gas plants (which have low fixed and high variable costs), non-fuel generation costs are taken to be one quarter of those for coal plants. The power transmission cost is taken to be 60 percent of the electricity generation cost in 2013, or $\$ 0.05$ per $\mathrm{kWh} .{ }^{48}$ The renewables subsidy is taken to be $\$ 0.03$ per kWh (Parry et al. 2016).

\footnotetext{
${ }^{45}$ For example, Jamil and Ahmad (2011), Table 1, report 26 estimates of long-run income elasticities for electricity from 17 studies, almost all of them lying within the above range.

${ }^{46}$ See, for example, GCEC (2014), Green and Stern (2016), Grubb et al. (2015), and IMF (2015).

${ }^{47}$ From Cao et al. (2013), pp 341 (after accounting for differences in coal prices).

48 This is approximately consistent with Cao et al. (2013), pp. 343.
} 
Road transport. In the road transport sector, consumption of gasoline and diesel was 96,471 ktoe and 170,729 ktoe respectively in 2013 (IEA 2016). Estimates of the income elasticity for $\mathrm{km}$ driven are typically between about 0.35 and 0.8 , although a few estimates exceed unity (Parry and Small 2005) and a central value of 0.6 is used. Numerous studies have estimated motor fuel (especially gasoline) price elasticities for different countries and some studies decompose the contribution of reduced vehicle $\mathrm{km}$ from improvements in average fleet fuel efficiencies. Based on this literature, a value of -0.25 is used for each of these elasticities and for both gasoline and diesel - the total fuel price elasticities are therefore - $0.5 .{ }^{49}$ The annual rate of decline in vehicle fuel consumption rates (from technological improvements) are set at 1 percent (e.g., Cao et al. 2013).

Other Energy Sector. We assume 50 percent of fuel consumption (from IEA 2016) for mining and quarrying, iron and steel, chemical and petrochemical, non-ferrous metals, paper, pulp and print, and non-metallic minerals is by large firms and potentially covered by the ETS and regulation. Fuel consumption by small energy users is total fuel consumption less fuel use in power generation, road transport, and large other energy users. Evidence on income and price elasticities for fuels used in the industrial and residential sectors is more limited. Based on judgement, the same income elasticities for coal and oil products are used as for electricity, while a value of 1.0 is assumed for natural gas and renewables products. Values for the usage and efficiency price elasticities for all fuels are taken to be the same as those for road fuels and electricity. The annual rate of productivity improvement follows those for the same fuel as used in the power sector.

GDP growth. Projected GDP out to 2021 is from the IMF's World Energy Outlook. From 2022 onwards, real GDP growth is assumed to decrease linearly from 6 to 5 percent in 2030 .

Mortality rates from fuel combustion. Coal accounts for the vast majority of air pollution deaths from fossil fuel combustion in China, primarily from fine particulates produced directly and formed indirectly (and in greater quantities) from sulfur dioxide $\left(\mathrm{SO}_{2}\right)$ and nitrogen oxide $\left(\mathrm{NO}_{\mathrm{x}}\right)$. China requires new coal plants are fitted with flue-gas desulfurization (FGD) equipment, is closing small-scale (high polluting) plants, and is requiring other existing plants to retrofit with FGD. As of 2010, FGD equipment had been installed on around 80 percent of electric coal plants (Cao et al. 2013, pp. 343), though even with these technologies plants still emit some $\mathrm{SO}_{2}$, in addition to $\mathrm{NO}_{\mathrm{x}}$ and direct particulates.

\footnotetext{
${ }^{49}$ There is, however, significant variation among studies: for example, Sterner (2007) reports globally averaged (long-run) gasoline price elasticities of around -0.7 while individual country estimates in Dahl (2012) are closer to about -0.25 on average (see Charap, da Silva and Rodriguez 2013 for further discussion). For a summary of evidence on the decomposition of the fuel price elasticities into the vehicle mileage and fuel efficiency responses see Parry and Small (2005). The responsiveness of fuel efficiency to taxation will be dampened in the presence of binding fuel economy regulations, though this issue is not so relevant for the present analysis which compares policies in isolation (rather than jointly).
} 
Air pollution mortality is taken from Parry et al. (2014), with some adjustments. Parry et al. (2014) estimate that the average coal plant in China caused 10.4 air pollution deaths per petajoule (PJ), or 0.435 deaths per ktoe, and the average coal plant with control technologies caused 5.3 deaths per PJ. In the absence of other factors, we assume the mortality rate from coal combusted at power plants and large industrial sources would converge linearly from 10.4 to 5.3 deaths per PJ between 2010 and 2030. However, the share of the Chinese population residing in urban areas is projected to increase by about 25 percent between 2010 and 2030 (Cao et al. 2013) and it is the urban population that is mostly exposed to air pollution. We therefore make a linear upward adjustment in the mortality rate each year to account for this, where the upward adjustment reaches 25 percent by 2030. For small-scale coal emissions, we assume the mortality rate is 10.4 deaths per PJ in 2010, rising in proportion to the rising share of the urban population.

Also based on Parry et al. (2014), 2010 the mortality rates for natural gas, gasoline, diesel, and oil products are taken to be 1.1 per PJ, 36 per billion liters, 124 per billion liters, and 20 per million barrels of other oil products respectively, and again these are scaled up for the rising urban population (though these fuels contribute only a small share to total mortality).

One caveat is that some evidence suggests people's channels for absorbing air pollution become saturated at very high outdoor pollution concentrations implying, paradoxically, that the health benefits from incremental reductions in fuel combustion are smaller at high pollution concentrations than at more moderate concentrations. ${ }^{50}$ In this regard, our analysis may overstate the domestic health benefits of carbon mitigation policies as it assumes incremental benefits are the same, regardless of pollution concentrations.

To value premature mortality, Parry et al. (2014) use a value of $\$ 1.13$ million per mortality for year 2010 based on extrapolating empirical evidence under an assumption that the income elasticity for this valuation is 0.8 . This figure is first increased by 15 percent to update it to year 2015\$ based on the average increase in consumer prices between 2010 and 2015 (see IMF 2016). And the 2010 figure is updated to future periods using future per capita income relative to 2010 raised to the power 0.8 .

Other externalities. Parry et al. (2014) estimate congestion, accident, and road damage externalities for gasoline and diesel vehicles at $\$ 0.86$ and $\$ 0.56$ per liter respectively for year 2010. This figure is updated to future periods in the same way as for the value of mortality. The additional parameter needed to compute fully efficient pricing policy is the social cost of carbon. For this we use US IAWG (2013)' value of \$60 for emissions in 2030 (expressed in year \$2015).

\footnotetext{
${ }^{50}$ That is, the relationship between mortality and pollution concentrations may be concave rather than linear (e.g., Burnett et al. 2013).
} 


\section{References}

Aldy, Joseph, et al., 2016. "Economic Tools to Promote Transparency and Comparability in the Paris Agreement." Nature Climate Change, forthcoming. Allcott, Hunt, and Nathan Wozny, 2013. "Gasoline Prices, Fuel Economy, and the Energy Paradox.” NBER Working Paper No. 18583, National Bureau of Economic Research, Cambridge, Massachusetts.

Arze del Granado, J., Coady, D. and Gillingham, R., 2012. "The Unequal Benefits of Fuel Subsidies: A Review of Evidence for Developing Countries." World Development 40(11), pp 2234-48.

Bernard, A.L., C. Fischer, and A.K. Fox, 2007. "Is There a Rationale for Output-based Rebating of Environmental Levies?" Resource and Energy Economics 29: 83-101.

Böhringer, C., J.C. Carbone and T.F. Rutherford. 2012. Unilateral Climate Policy Design: Efficiency and Equity Implications of Alternative Instruments to Reduce Carbon Leakage. Energy Economics 34 (Supplement 2): S208-S217 (December).

Brauer, Michael, Markus Amann, Rick T. Burnett, Aaron Cohen, Frank Dentener, Majid Ezzati, Sarah B. Henderson, Michal Krzyzanowski, Randall V. Martin, Rita Van Dingenen, Aaron van Donkelaar, and George D. Thurston, 2012, "Exposure Assessment for Estimation of the Global Burden of Disease Attributable to Outdoor Air Pollution," Environmental Science and Technology 46, 652-60.

Burnett, Richard T., C. Arden Pope, Majid Ezzati, Casey Olives, Stephen S. Lim, Sumi Mehta, Hwashin H. Shin, and others, 2013, "An Integrated Risk Function for Estimating the Global Burden of Disease Attributable to Ambient Fine Particulate Matter Exposure" (Unpublished; Ottawa, Ontario, Canada: Health Canada).

Calder, Jack, 2015. “Administration of a U.S. Carbon Tax.” In Implementing a U.S. Carbon Tax: Challenges and Debates, edited by I. Parry, A. Morris, and R. Williams, New York, Routledge, 38-61.

Cao, Jing, Mun S. Ho, and Dale W. Jorgenson, 2013. "The Economics of Environmental Policies in China." In C.P. Nielsen and M.S. Ho (eds.), Clearer Skies over China:

Reconciling Air Quality, Climate, and Economic Goals, MIT Press, Cambridge, MA, pp. 329-373. 
Charap, Joshua, Arthur Ribeiro da Silva and Pedro Rodriguez, 2013. "Energy Subsidies and Energy Consumption-A Cross Country Analysis.” Working paper 13-112, International Monetary Fund, Washington, DC.

Coady, D., and Newhouse, D., 2006. "Evaluating the distribution of the real income effects of increases in petroleum product prices in Ghana." In A. Coudouel, A. Dani and S.

Paternostro, eds., Analyzing the distributional impacts of reforms: Operational experience in implementing poverty and social impact analysis, World Bank, Washington DC.

Dahl, Carol, A., 2012. Measuring Global Gasoline and Diesel Price and Income Elasticities." Energy Policy 41: 2-13.

Dechezleprêtre Antoine and David Popp, 2016. "Fiscal and Regulatory Instruments for Clean Technology Development in the European Union.” Paper presented at a conference Energy Tax and Regulatory Policy in Europe: Reform Priorities and Research Needs, Ifo Institute, Munich, November 2014.

Dinan, Terry. 2015. “Offsetting a Carbon Tax's Burden on Low-Income Households.” In Implementing a US Carbon Tax: Challenges and Debates, edited by I. Parry, A. Morris, and R. Williams, 38-61. New York: Routledge.

Fawcett, Allen A., Leon C. Clarke, and John P. Weyant, 2015. "Carbon Taxes to Achieve Emissions Targets: Insights from EMF 24.” In Implementing a U.S. Carbon Tax: Challenges and Debates, edited by I. Parry, A. Morris, and R. Williams, New York, Routledge, 62-82.

Fullerton, Don, and Garth Heutel. 2011. "Analytical General Equilibrium Effects of Energy Policy on Output and Factor Prices." The B.E. Journal of Economic Analysis \& Policy 10: 126.

Gillingham, Kenneth, David Rapson, and Gernot Wagner, 2016. "The Rebound Effect and Energy Efficiency Policy.” Review of Environmental Economics and Policy 10: 68-88.

GCEC, 2014. China and the New Climate Economy. Global Commission on the Economy and Climate. Tsinghua University, Beijing.

Green, Fergus and Nicholas Stern, 2016. "China's Changing Economy: Implications for its Carbon Dioxide Emissions." Centre for Climate Change Economics and Policy, Working Paper 258. 
Grubb, M., Sha, F., Spencer, T., Hughes, N., Zhang, Z., and Agnolucci, P., 2015. "A review of Chinese $\mathrm{CO}_{2}$ Emission Projections to 2030: the Role of Economic Structure and Policy." Climate Policy 15(S1), S7-S39.

Harberger, Arnold C., 1964. "The Measurement of Waste". American Economic Review 54: $58-76$.

Harrington, Winston, 2012. "Improving Fuel Economy in Heavy-Duty Vehicles.” Discussion paper 12-02, Resources for the Future, Washington, DC.

Hassett, K., A. Mathur, and G. Metcalf. 2009. "The Incidence of a US Carbon Tax: A Lifetime and Regional Analysis.” Energy Journal 30: 155-78.

Helfand, Gloria, and Ann Wolverton, 2011. "Evaluating the Consumer Response to Fuel Economy: A Review of the Literature." International Review of Environmental and Resource Economics 5: 103-46.

IMF, 2016. World Economic Outlook. International Monetary Fund, Washington, DC.

IMF, 2015. People's Republic of China: Staff Report for the 2015 Article IV Consultation. International Monetary Fund, Washington, DC.

International Energy Agency (IEA), 2016. World Energy Balances. www.oecdilibrary.org/energy/data/iea-world-energy-statistics-and-balances/world-energybalances_data-00512-en.

Jamil, Faisal and Eatzaz Ahmad 2011. "Income and price elasticities of electricity demand: Aggregate and sector-wise analyses.” Energy Policy 39: 5,519-527.

Karplus, Valerie J., Sebastian Rausch and Da Zhanga, 2016. "Energy Caps: Alternative Climate Policy Instruments for China?” Energy Economics 56: 422-431.

Krupnick, Alan J., Ian W.H. Parry, Margaret Walls, Tony Knowles, and Kristin Hayes, 2010. Toward a New National Energy Policy: Assessing the Options. Washington DC, Resources for the Future and National Energy Policy Institute.

Lam, W. Raphael and Philippe Wingender, 2015. "China: How Can Revenue Reforms Contribute to Inclusive and Sustainable Growth?," IMF Working Paper 1566, Washington DC.

Lillard, L. A. 1977. "Inequality: Earnings versus Human Wealth.” American Economic Review 67: 42-53. 
Löschel, Andreas and Oliver Schenker, 2016. "On the Coherence of Economic Instruments: Climate, Renewables and Energy Efficiency Policies.” Paper presented at a conference Energy Tax and Regulatory Policy in Europe: Reform Priorities and Research Needs, Ifo Institute, Munich, November 2014.

Lucas, Robert, 1990. “Supply-Side Economics: An Analytical Review.” Oxford Economic Papers 42: 293-316.

Mischke, Peggy and Kenneth B. Karlsson, 2014. "Modelling Tools to Evaluate China's Future Energy System - A Review of the Chinese Perspective.” Energy 69: 132-143.

Morris, Adele, and Aparna Mathur. 2015. "The Distributional Burden of a Carbon Tax: Evidence and Implications for Policy." In Implementing a US Carbon Tax: Challenges and Debates, edited by I. Parry, A. Morris, and R. Williams, 38-61. New York: Routledge.

National Research Council (NRC), 2009. Hidden Costs of Energy: Unpriced Consequences of Energy Production and Use (Washington: National Research Council, National Academies).

Organization for Economic Cooperation and Development (OECD), 2012. Mortality Risk Valuation in Environment, Health and Transport Policies (Paris: Organization for Economic Cooperation and Development).

Parry, Ian, 2004. “Are Emissions Permits Regressive?,” Journal of Environmental Economics and Management, 47: 364-387.

Parry, Ian W.H. and Kenneth A. Small, 2005. "Does Britain or The United States Have the Right Gasoline Tax?” American Economic Review 95: 1,276-1,289.

Parry, Ian W.H., David Evans, and Wallace E. Oates, 2014. "Are Energy Efficiency Standards Justified?” Journal of Environmental Economics and Management 67: 104-25.

Parry, Ian W.H., Dirk Heine, Shanjun Li, and Eliza Lis, 2014. Getting Energy Prices Right: From Principle to Practice. International Monetary Fund, Washington, DC.

Parry, Ian W.H., Baoping Shang and Philippe Wingender, 2016. Working paper, International Monetary Fund, Washington, DC.

Poterba, James M. 1991. "Is the Gasoline Tax Regressive?" In Tax Policy and the Economy, edited by David Bradford, 5. Cambridge, Massachusetts: National Bureau of Economic Research. 
Rausch, S., G. E. Metcalf, and J. M. Reilly. 2011. "Distributional Impacts of Carbon Pricing: A General Equilibrium Approach with Micro-Data for Households." Energy Economics 33 (S1): S20-S33.

Sterner, Thomas. 2007. "Fuel Taxes: An Important Instrument for Climate Policy." Energy Policy 35: 3,194-202.

Timmer, M. P., E. Dietzenbacher, B. Los, R. Stehrer, and G. J. de Vries. 2015. “An Illustrated User Guide to the World Input-Output Database: The Case of Global Automotive Production." Review of International Economics. doi: 10.1111/roie.12178.

UNEP, 2015. The Chinese Automotive Fuel Economy Policy: February 2015 Update. United Nations Environment Program.

United States Inter-Agency Working Group (US IAWG), 2013. "Technical Update of the Social Cost of Carbon for Regulatory Impact Analysis Under Executive Order 12866." Washington.

WB/SEPAC 2007. Cost of Pollution in China: Economic Estimates of Physical Damages. World Bank and State Environmental Protection Agency of China, Washington DC, World Bank. 